\title{
WestVirginiaUniversity
}

THE RESEARCH REPOSITORY @ WVU

Graduate Theses, Dissertations, and Problem Reports

2010

\section{Utilization of leaf meal as a potential feed source}

Jason K. Smith

West Virginia University

Follow this and additional works at: https://researchrepository.wvu.edu/etd

\section{Recommended Citation}

Smith, Jason K., "Utilization of leaf meal as a potential feed source" (2010). Graduate Theses, Dissertations, and Problem Reports. 2980.

https://researchrepository.wvu.edu/etd/2980

This Thesis is protected by copyright and/or related rights. It has been brought to you by the The Research Repository @ WVU with permission from the rights-holder(s). You are free to use this Thesis in any way that is permitted by the copyright and related rights legislation that applies to your use. For other uses you must obtain permission from the rights-holder(s) directly, unless additional rights are indicated by a Creative Commons license in the record and/ or on the work itself. This Thesis has been accepted for inclusion in WVU Graduate Theses, Dissertations, and Problem Reports collection by an authorized administrator of The Research Repository @ WVU. For more information, please contact researchrepository@mail.wvu.edu. 


\section{Utilization of Leaf Meal as a Potential Feed Source}

\section{Jason K. Smith}

Thesis submitted to the

College of Agriculture, Natural Resources and Design

at West Virginia University

in partial fulfillment of the requirements for the degree of

Master of Science

Animal and Nutritional Sciences

Eugene E.D. Felton, Ph.D., Chair

Joseph S. Moritz III, Ph.D.

John E. Warren, Ph.D.

Department of Animal and Nutritional Sciences

Morgantown, WV

2010

Keywords: Leaf Meal, Alternative Feeds, Ruminant 


\section{Abstract \\ Utilization of Leaf Meal as a Potential Feed Source}

Jason K. Smith

Alternative feeds are currently utilized by producers throughout much of animal agriculture as a method of reducing feed costs. Under careful resource management, and proper understanding of their potential effects on animal performance, some deciduous tree leaves may prove to be a valuable feed resource, as substantial tonnage exists in the forests of the United States. In order to assess their value as a feed source, fall-dropped Quercus alba (white oak) and Liriodendron tulipifera (tulip poplar) leaves were collected at the Appalachian Farming Systems Research Center in Beaver, WV by the USDA-ARS. Proximate analysis and fiber determination, as well as Prussian blue and protein precipitation assays were used to determine the chemical composition of white oak (WOLM) and tulip poplar (TPLM) leaf meals, in order to determine their potential utilization as a feed source for ruminant livestock animals. Leaf meals were further evaluated as components of complete diets. In-situ ruminal dry matter digestibility (DMD) of WOLM and TPLM was determined by incubation for $0,1,2,4,8,12,24,48$, and 72 hours via a switch-back design in the rumen of two non-lactating dairy cows fed a corn silage- and grass haylage-based diet. In-situ ruminal DMD of WOLM did not differ $(\mathrm{P}>0.05)$ at $0,1,2$, and 4 hours, but increased $(\mathrm{P}<0.01)$ at $8,12,24,48$, and 72 hours of incubation. In-situ ruminal DMD of TPLM tended to increase at $1(\mathrm{P}=0.06)$ and $2(\mathrm{P}=$ $0.08)$ hours of incubation, while it increased $(\mathrm{P}<0.05)$ at all subsequent time points. Following the onset of digestion, rate of In-situ ruminal DMD appeared to increase through 24 hours of ruminal incubation for both WOLM and TPLM, while it appeared to decline after 24 hours of incubation in the rumen. Results indicate that WOLM and TPLM provide a readily digestible source of dry matter for ruminants. White oak leaf meal and TPLM were utilized as replacements for soybean hulls at 10 and 20 percent of total dietary DM in pelleted growing lamb diets to evaluate their potential as an alternative feed source for ruminants. Protein precipitating capacity of experimental growing lamb diets decreased $(\mathrm{P}<0.01)$ as a result of pelleting, indicating destruction or inactivation of associated protein-precipitating compounds. Replacement of SBH with leaf meal improved pellet quality $(\mathrm{P}<0.001)$, while replacement decreased dry matter $(\mathrm{P}$ $<0.01)$, neutral detergent fiber $(\mathrm{P}<0.05)$, acid detergent fiber $(\mathrm{P}<0.01)$, and organic matter $(\mathrm{P}<0.05)$ digestibility's of pelleted experimental growing lamb diets, without affecting $(\mathrm{P}>0.05)$ dry matter intake expressed as a percentage of body weight, or crude protein digestibility. Likewise, plasma urea nitrogen, urinary urea nitrogen, and urinary crude protein were unaffected $(\mathrm{P}>0.05)$ by replacement of soybean hulls with WOLM or TPLM. White oak leaf meal and TPLM appear to be readily digestible feedstuffs that show potential for utilization as alternative feed sources for ruminant livestock animals. 


\section{Acknowledgements}

I would like to express my gratitude to all who have helped to make my career as a graduate student a success. First, I would like to thank my major advisor, Dr. Gene Felton, who graciously provided me with the opportunity to become a member of his research group. I would also like to thank Dr. Felton for his support and guidance, both related and unrelated to academia. I would like to thank Dr. Joe Moritz, who provided me with the opportunity to work in conjunction with his feed manufacturing research group, as well as Dr. John Warren and Dr. Paul Lewis, who provided me with teaching opportunities while completing my research and degree requirements. I would also like to thank these faculty members for their encouragement and advice throughout the past few years.

I would like to express my thankfulness to my lab mates, Kevin Shaffer, for his countless amount of help and support, as well as Eric Nestor and Quinn Baptiste, for their assistance and advice. I would also like to express a thank you to Curran Gehring for his great amount of assistance, support, and advice. These are friendships which I hope and am sure will last throughout a lifetime. A big thank you also goes out to Erika Mastalerz and Stephanie Pauley, for their seemingly endless amount of assistance in the lab as well as throughout the growing lamb metabolism study.

I would like to thank Jim Neel and his group at the USDA-ARS Appalachian Farming Systems Research Center in Beaver, WV for their assistance and providing me with a much needed resource for this research. I would also like to thank my feed manufacturing colleagues Nancy Buchanan, Kelly Lily, Amanda Rack, Casey Martin, 
Kayla Beaman, Stacey Loop, and Laurel Shires, for their time and assistance in the feed mill. I must also express my thankfulness to Tammy Webster and Sarah Beamer for their cooperation and assistance. A sincere thank you also goes out to the West Virginia University Animal and Nutritional Sciences office support staff for the seemingly endless amount of assistance that you have provided throughout the past few years. I would also like to thank Mrs. Jo Gulley, as well as the entire Division of Animal Feeds at the U.S. Food and Drug Administration's Center for Veterinary Medicine for giving me the opportunity to begin a career while subsequently completing my degree.

I would like to express my deepest gratitude to my family; my parents, John and Carolyn Smith, my siblings, Kimberly Huffman and Ethan Smith, and my grandparents, Hazel and Bill McAmis, and Margaret and Dean Smith, for their endless support, patience, and encouragement. 


\section{Table of Contents}

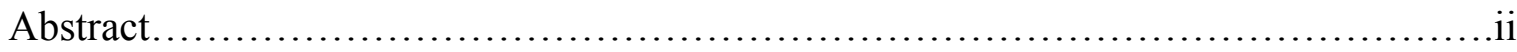

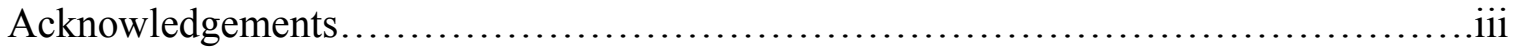

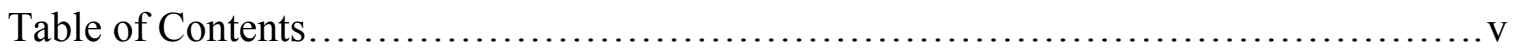

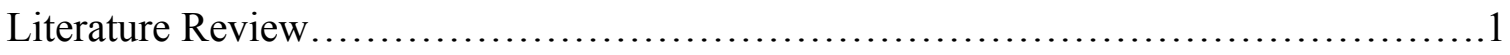

Alternative Feeds................................................................ 1

Eastern Forest Composition, Population, and Acreage ........................... 9

Tannins in Feedstuffs.................................................. 10

Anti-parasitic Effect of Tannins...........................................19

Bloat Reduction with Tannins............................................... 20

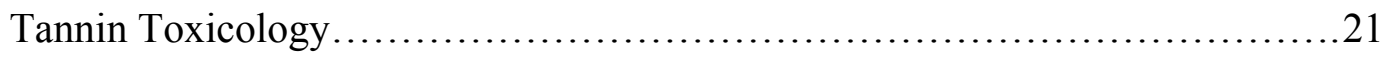

Analysis of Phenolic Compounds in Feedstuffs................................ 22

Inactivation of Tannins in Feedstuffs........................................ 24

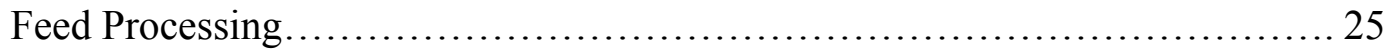

Induced Molting of Laying Hens............................................. 35

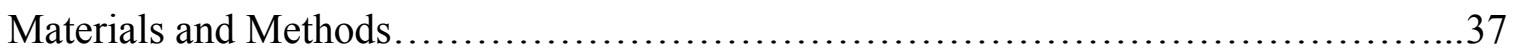

General Leaf Harvest and Preparation........................................ 37

Leaf Meal Chemical Composition........................................... 37

Proximate Analysis and Fiber Determination............................37

Phenol Analysis.................................................... 38

In situ Ruminal Dry Matter Digestibility of White Oak and Tulip Poplar Leaf

Meals....................................................................... 42 
Feed Manufacture and Growing Lamb Metabolism.

Experimental Design............................................43

Experimental Diet Formulation and Feed Manufacture................. 44

Experimental Diet Chemical Composition........................... 45

Proximate Analysis and Fiber Determination...................45

Phenol Analysis......................................... 46

Experimental Diet Pellet Quality.................................. 46

Growing Lamb Metabolism................................... 47

Statistical Analyses...................................................... 49

Results and Discussion.................................................. 50

Leaf Meal Chemical Composition....................................... 50

Proximate Analysis and Fiber Determination.......................50

Phenol Analysis............................................. 50

In situ Ruminal Dry Matter Digestibility of White Oak and Tulip Poplar Leaf

Meals............................................................... 51

Feed Manufacture and Growing Lamb Metabolism.......................... 52

Phenol Analysis of Experimental Growing Lamb Diets.................52

Experimental Diet Pellet Quality................................. 54

Growing Lamb Metabolism....................................54

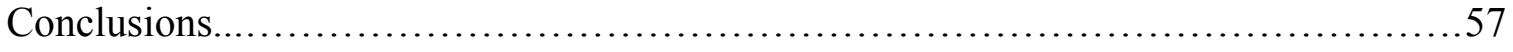

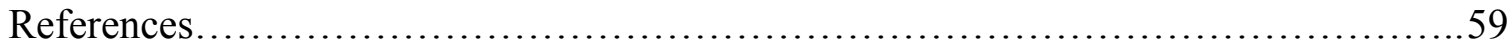

Figures................................................................ 75 
Figure 1. In-situ dry matter digestibility of tulip poplar and white oak leaf meals.

Tables. .76

Table 1. Ingredient composition of pelleted experimental growing lamb diets ${ }^{1} . .76$ Table 2. Proximate analysis and fiber determination ${ }^{1}$ of pelleted experimental growing lamb diets ${ }^{2}$

Table 3. Proximate analysis and fiber determination ${ }^{1}$ of white oak and tulip poplar leaf meals.

Table 4. Phenol analysis ${ }^{1}$ of white oak and tulip poplar leaf meals.

Table 5. Phenol analysis ${ }^{1}$ of pelleted and non-pelleted experimental growing lamb diets ${ }^{2}$ .80

Table 6. Pellet quality ${ }^{1}$ of experimental growing lamb $\operatorname{diets}^{2}$.

Table 7. Dry matter intake ${ }^{1}$ and In vivo digestibility ${ }^{2}$ of pelleted experimental growing lamb diets ${ }^{3}$

Table 8. In vivo nitrogen metabolism ${ }^{1}$ of pelleted experimental growing lamb diets. 


\section{Literature Review}

\section{$\underline{\text { Alternative Feeds }}$}

Alternative feeds have been shown to be beneficial in many ruminant feeding programs, particularly in the cow/calf and feedlot sectors of the beef industry. Feed costs often make up approximately forty to eighty percent of annual production costs in typical animal production systems, and in many enterprises are considered the largest cost associated with production (Hersom, 2006; Wahlberg, 2009). Recently, lamb feeders have also shown interest in utilization of alternative feedstuffs as a result of high costs of commercially manufactured protein supplements (Held, 2006). As with all businesses, a main goal of livestock producers is to optimize production while achieving maximum profit. One method utilized to achieve this goal involves decreasing costs associated with production. Alternative feeds are often considered an effective method of reducing cost of diet, in turn reducing cost of gain (DiCostanzo et al., 1994). Alternative feeds produced as by- or co-products of the corn-, oat-, soybean-, and wheat-milling, as well as cotton- and sugar beet-processing industries are commonly available throughout much of the United States.

Some factors that affect the feasibility and justification of alternative feedstuff usage include costs, availability, nutrient variation, as well as potential for spoilage and toxicity. Cost per unit of nutrient provided is a factor of great importance to livestock production and animal nutrition when evaluating the potential utilization of a particular alternative feedstuff as a replacement for a conventional feedstuff or another alternative feedstuff. Alternative feedstuff costs are often affected by their availability, handling 
characteristics, and proximity. Often times, in areas where alternative feedstuff production is not in close proximity to the area where livestock are fed, utilization is infeasible and not justifiable due to transportation and storage costs. In areas where alternative feedstuffs are readily available, or transportation costs are low, utilization is often justified. In many instances, the ultimate feasibility of an alternative feedstuff may lie in its ability to fill a niche need, or in the diversity of which that feedstuff can be used.

Currently, some of the most readily available and widely utilized alternative feeds are those produced by both the dry and wet corn milling processes. Dry-milling is most often the process utilized in corn-based ethanol production. During this process, starch from corn grain is fermented to produce ethanol. After distillation and removal of the ethanol, the whole stillage is centrifuged, separating the thin stillage, which is often added back as solubles, or marketed as a water replacement for finishing feedlot steers. The remaining centrifuged whole stillage is then marketed after or without the addition of solubles, as distiller's wet grains with or without solubles, or dried and marketed as distiller's dried grains with or without solubles. Corn grain is composed of approximately two-thirds starch. Removal of starch during the fermentation process results in a three-fold concentration of other components, which mainly include protein, fat, and fiber (Loy and Miller, 2008). As a result, distiller's grains are considered protein and energy supplements for ruminants, dependant upon to which ingredient the byproduct is used as an alternative.

Distiller's wet and dried grains with solubles have a much lower cost per unit of energy when compared to corn. The ability of distiller's byproducts to effectively replace a portion of dietary corn inclusion for finishing cattle and lambs has been reported 
extensively in the literature. Meta-analysis (Klopfenstein et al., 2008) of reported literature showed that cattle fed diets that contained distiller's wet grains with solubles exhibited higher average daily gains (ADG) and feed efficiency (FE) when compared to cattle fed corn-based diets without distiller's wet grains with solubles. Likewise, a subsequent meta-analysis of additional work showed that cattle fed diets that contained distiller's dried grains with solubles exhibited higher ADG and FE when compared to cattle fed corn-based diets without distiller's dried grains with solubles, but to a lesser extent when compared to distiller's wet grains with solubles inclusion (Klopfenstein et al., 2008). Similar to the effect reported in finishing feedlot cattle, inclusion of distiller's dried grains with solubles at levels up to 60 percent of dietary dry matter (DM) had no negative effect on finishing lamb performance (Erickson et al.,1989, Schauer et al., 2005 and 2008). Distiller's grains with solubles utilization in finishing lamb diets, however, is almost exclusive to the dried form due to wide-scale incorporation of pelleting to finishing lamb diets throughout the United States.

In a 2007 survey of Midwestern consulting feedlot nutritionists, Vasconcelos and Galyean reported that 82.76 percent of nutritionists surveyed incorporate corn-based coproducts from the ethanol industry in finishing feedlot diet formulations. Of those coproducts, distiller's wet grains with solubles and distiller's dried grains with solubles were the most widely utilized. Abundance, along with lower cost per unit of energy of these co-products has resulted in extensive utilization as a substitute or replacement for corn or other grains as an energy source throughout much of the U.S. ruminant feeding industry. 
Similar to the previous comparison with corn as an energy source, distiller's dried grains with solubles has a much lower cost per unit of protein when compared to soybean meal, indicating potential for use as an alternative protein source. Huls et al. (2006) effectively replaced 100 percent of the dietary DM from soybean meal with distiller's dried grains with solubles without affecting finishing performance of wether lambs that received corn and soybean hull (SBH) based finishing rations.

Wet-milling of corn is most commonly defined as the process utilized to separate corn into starch, germ, and bran during the production of corn syrup and extraction of corn oil. This process produces co-products of value to ruminant feeders, such as corn gluten feed and corn gluten meal. Corn gluten feed is composed of a mixture of corn bran, as well as steepwater solubles, and may contain corn germ meal. Corn gluten meal is composed mainly of the proteinaceous portion of the corn kernel. Often used as a bypass protein supplement, price of corn gluten meal often limits utilization as an alternative feedstuff in ruminant feeding programs (Loy and Miller, 2008).

Corn gluten feed is considered as both an energy and a protein supplement, and is often available in wet, dried, and dried-pellet forms. Similarly to distiller's wet grains with solubles and distiller's dried grains with solubles, nutrient composition of corn gluten feed varies, depending upon the variance in production processes between plants. Corn gluten feed protein and net energy for gain values increase as corn steepwater soluble inclusion increases and bran inclusion decreases (Stock et al., 2000). Wet corn gluten feed tends to have a slightly higher energy value when compared to dried corn gluten feed (Stock et al., 2000) as a result of volatilization of fatty acids during the drying process (Lardy and Anderson, 2009). Contrary to what the name indicates, corn gluten 
feed contains no gluten (Loy and Miller, 2008). Firkins et al. (1985) reported the ability of wet and dried corn gluten feed to be fed at levels of, but not limited to 50 percent of dietary DM as an alternative to corn in finishing feedlot diets, while improving ADG and dry matter intake (DMI). Parsons et al. (2007) reported an increase in FE and DMI when wet corn gluten feed was used as a replacement for 20 and 40 percent of steam-flaked corn in finishing feedlot steer diets. Vasconcelos and Galyean (2007) reported that wet corn gluten feed and dried corn gluten feed are utilized as secondary replacements or substitutes for corn as an energy source by surveyed consulting Midwestern feedlot nutritionists.

Utilization of byproducts from the wet corn milling industry as ruminant feedstuffs creates some potential concern. Traditionally, sulfur dioxide is utilized to soften the corn kernel (Minnesota Corn Growers Association, 2001). This results in high sulfur levels of resulting byproduct feeds, such as corn gluten feed and corn gluten meal. Sulfur level, however, is dependant upon the level of condensed steepwater added back to the feeds. The National Research Council (NRC) considers the maximum tolerable concentration of sulfur in diets for cattle to be 0.4 percent dietary DM (National Research Council, 1996). Likewise, the NRC considers the maximum tolerable concentration of sulfur in diets for small ruminants to be 0.3 and 0.5 percent of dietary DM for concentrate and forage-based diets, respectively (National Research Council, 2007). Consumption of diets containing sulfur levels exceeding the maximum tolerable concentration may lead to sulfur toxicity, or polioencephalomalacia (Gould, 1998).

Soybean hulls, a co-product of the soybean processing industry, consist of the fibrous outer-coating of the soybean. Hulls are removed by air-stream after crushing or 
grinding of whole soybeans, and prior to oil extraction of SBM. After removal, SBH are heat-treated to destroy urease activity (Lalman, 1996). Soybean hulls are often available in pellet form due to the associated improved handling and manufacturing characteristics.

Soybean hulls are considered a "safe" energy source for ruminants due to their highly digestible fibrous makeup (Held, 2006a), but do not show potential for utilization as an alternative to corn in cattle finishing programs at inclusion levels of greater than twenty percent of dietary DM. Hsu et al. (1987) reported decreased FE of finishing steers that received SBH as an alternative to corn at levels of 25 and 50 percent of total dietary DM. Steers that received SBH as an alternative energy source exhibited higher DMI with no significant effect on ADG (Hsu et al., 1987). A study conducted by Ludden et al. (1995) confirmed that SBH are unable to replace corn at levels of 20, 40, and 60 percent of dietary DM with or without the addition of 5 percent fat, without adversely affecting finishing steer performance.

Soybean hulls, however, have proven to be an effective alternative to corn as an energy source for finishing lambs. Hejazi et al. (1999) reported increased DMI and ADG, without affecting FE of finishing lambs when 10 percent of total dietary DM from corn was replaced with SBH. Zelinsky et al. (2006) reported increased DMI and FE with no difference in ADG when SBH pellets replaced 100 percent of dietary DM from corn in finishing lamb diets, and established the potential of SBH as an alternative energy source for corn in the diet of finishing lambs.

Co-products of cotton processing have proven to be beneficial feedstuffs to ruminant nutrition; primarily, cottonseed hulls. Removal of the hull, or the fibrous outer covering, of cottonseed is often the initial step in cottonseed processing. One issue 
associated with cotton byproduct utilization is the presence of gossypol, a potentially toxic polyphenol pigment. Gossypol is found mainly in the seed and oil fractions of the whole cottonseed, and is only toxic in its free, non-protein-bound form. Level and activity of gossypol is dependant upon various factors, including environment and cotton variety. Free gossypol is often detected at a very low level in the hull fraction of the whole cottonseed. The presence of this gossypol, however, is suggested to be present in the small amount of seed and oil that remains after processing of whole cottonseed, as pure cottonseed hulls contain no polyphenol pigments, and is of little to no concern to finishing ruminants. Free gossypol detected in cottonseed hulls appears to be reduced, destroyed, or bound to protein as a result of the pelleting process (Blasi and Drouillard, 2002).

Due to high fiber content, cottonseed hulls are often incorporated as a roughage source, and utilized as an alternative to forage in finishing ruminant diets. Guthrie et al. (1996) reported that heifers that received 7.5 or 15 percent dietary DM of alfalfa hay as a roughage source exhibited lower DMI and ADG when compared to heifers that received 7.5 or 15 percent dietary DM of cottonseed hulls as a replacement for alfalfa hay, respectively. As reviewed by Defoor et al. (2002), this study showed that cottonseed hulls can effectively replace 100 percent of dietary DM from alfalfa hay as the roughage source in steam-flaked corn based diets for finishing cattle without adversely affecting performance. Additionally, researchers reported increases in DMI as well as ADG, without negatively affecting FE as a result of replacement of alfalfa hay with cottonseed hulls (Defoor et al., 2002). 
Co-products of the cereal grain milling industry are abundantly available to livestock feeders throughout the United States, due mainly to the geographic diversity and abundance of cereal grain milling. Of these cereal grains, wheat is the most commonly milled for human consumption throughout the United States. Bran, aleurone, and germ are removed from the kernel during the wheat milling process, leaving the remaining starch, which makes up approximately 72 percent of wheat grain. Bran and germ, removed from the kernel with rollers, are then mixed with ground screenings from the grain cleaning process, along with remnants of starch from rejected flour, and offal from the milling process, to produce wheat middlings (Dhuyvetter et al., 1999). Dalke et al. (1997) reported effective replacement of 5 percent of total dietary DM from dry-rolled corn with wheat middlings in finishing feedlot steer diets without significantly affecting ADG or FE. Replacement of dry-rolled corn with wheat middlings at levels of 10 and 15 percent of dietary DM significantly decreased FE without affecting ADG. Dry matter intake was positively correlated (linear) with wheat middling inclusion level. In the same study, researchers effectively utilized wheat middlings as a roughage source to replace 50 and 100 percent of DM from alfalfa hay without significantly affecting ADG or FE, while decreasing DMI (Dalke et al., 1997).

The above mentioned co- and by-product feeds are just a few of the commonly accepted alternative feedstuffs that are utilized widely in today's animal feeding enterprises. When first available, producers hesitated to utilize these feedstuffs. However, hesitation toward their utilization dissipated through reported investigation of their compositional analysis and associated feeding effects. As animal agriculture persists, economics and continued pressure toward utilization of alternatives to common 
feedstuffs will continue to drive the investigative discovery of new alternative feed resources.

\section{Eastern Forest Composition, Population, and Acreage}

By definition, alternative feeds may in fact be anything that under normal feeding strategies are not traditionally used as an animal feed. Many such feeds are also commonly referred to as by-product or co-product feeds, and are secondary manufacturing products that were at one time considered wastes. More recently however, as a result of increased competition for grains for ethanol production, as well as a poor economic state, alternative feed sources are being utilized by producers throughout much of animal agriculture. In particular, many alternative feeds that are being used extensively in diets for ruminant livestock throughout much of the United States at one time would not have been considered high quality feedstuffs.

Under careful resource management and proper understanding of their potential effects on animal performance, a potential feed resource with substantial tonnage exists in the forests of the United States. Seventy eight percent of the state of West Virginia is covered by leaf bearing forests (USDA Economic Research Service, 2007; USDA Forest Service, 2006). One of the main biological purposes of a leaf is to capture energy from sunlight and transform it into energy in the form of carbohydrates. This is achieved through many nutrient rich components of the leaf's cellular structure. Many of these nutrients may have potential value in meeting the needs of agricultural animals. Forests of the eastern United States, including West Virginia are primarily inhabited by hardwood tree species. Of those, two common species include Quercus alba (white oak) 
and Liriodendron tulipifera (tulip poplar). It has been estimated that West Virginia forests alone are home to approximately 790,809,226 live white oak and 518,980,499 live tulip poplar trees (USDA Forest Service, 2006). Leaf mass produced by such a vast population of trees is substantial. Traditionally, mature, fall-dropped leaves are not collected and are recycled on the forest floor as leaf litter. Similarly, the vast majority of foliage produced by urban trees is collected and disposed of in landfills. One may question, can nutrients within these leaves be captured and utilized as a potential feed source? If so, what are the nutritional concerns or potential methods of utilization?

\section{$\underline{\text { Tannins in Feedstuffs }}$}

Numerous reports have demonstrated that tree leaves, especially those of the Quercus family, contain substantial levels of phenolic or tannin-like compounds. Similarly, phenolic compounds are a component of various grain, forage, and browse species commonly utilized in livestock diets throughout much of the world. One major classification of polyphenols in plant tissue is tannins (Mangan, 1988). Tannins are water-soluble compounds, generally ranging from a molecular weight of 500 to 3000 , that contain sufficient hydroxylic phenol groups in order to crosslink with protein, as well as other molecules (Goldstein and Swain, 1963; Swain, 1979). Tannins may be broken into two major classifications as they relate to livestock feeds; proanthocyanidins, also known as condensed tannins; and hydrolysable tannins (Kumar and Singh, 1984).

Condensed tannins are considered to be the most common plant tannins, consisting of catechin oligomers that normally produce anthocyanidins after acid degradation. Hydrolysable tannins are composed of a carbohydrate center along with gallic acid or $m$ - 
digallic acid (gallotannins), or hexahydroxydiphenic acid (ellagitannins), and are easily hydrolysed (Mangan, 1988).

Hydrolysable and condensed tannins are found in many common feedstuffs utilized throughout production animal agriculture. Most monocotyledonary plants, such as grasses contain negligible levels of tannins (McLeod, 1974), with exception to many cereal grains, such as Sorghum vulgare (sorghum), Hordeum vulgare (barley), and Brassica napus (rapeseed), which contain appreciable amounts of tannins (Jansman, 1993). The majority of tannin-rich feedstuffs belong to the Leguminosae family (Salunkhe et al., 1990). Salunkhe et al. (1990) reported that many conventional forage legumes utilized throughout the United States contain appreciable amounts of tannins; including Medicago sativa (alfalfa), Trifolium repens (white clover), Trifolium pretense (red clover), Lespedeza cuneata (sericea lespedeza), and Melilotus officinalis (sweetclover). Other forage legumes, such as Lotus pedunculatus (big trefoil) and Lotus corniculatus (birdsfoot trefoil) have been credited with containing tannins as well (Barry and Manley, 1984; O’Donovan and Brooker, 2001). Roughages such as CSH have also been found to contain tannins (Yu et al., 1995). Particularly, herbaceous legumes of the Quercus species contain appreciable amounts of both hydrolysable and condensed tannins, and are considerably important feedstuffs for ruminants throughout relatively arid regions (Vitti et al., 2005; Mupangwa et al., 2000; Mangan, 1988; Kumar and Singh, 1984). Kumar and Vaithiyanathan (1990) reviewed the occurrence of tannins in many tree or shrub species utilized in animal agriculture.

Scarcity of conventional forage in drought-stricken portions of the United States often leads to browsing of tannin-rich fodder tree leaves by ruminants. Likewise, 
unavailability of conventional feeds in developing countries often leads to incorporation of tannin-rich feedstuffs in ruminant diets.

Tannins have both detrimental and beneficial effects on nutrient metabolism and ruminant nutrition (Kumar and Singh, 1984; Perez-Maldonado et al., 1995). Addition of adsorbents to tannin-containing feedstuffs has been reviewed extensively throughout the literature, and is often used as a widely-accepted means of determining nutritional or physiological effects of tannins to animals. Loomis (1974) suggested that tannins bind more strongly to polyvinylpyrrolidone and polyethylene glycol than proteins. Barry and Manley (1984) reported decreased organic matter digestibility (OMD) of high-tannin big trefoil in growing lambs compared to those that received polyethylene glycol treated high-tannin big trefoil. Similarly, Barahona et al. (1997) reported a trend for decreased OMD of both Desmodium ovalifolium and Flemingia macrophylla in growing wether lambs compared to lambs that received polyethylene glycol treated forage.

In the same experiment Barahona et al. (1997) reported decreased neutral detergent fiber (NDF) digestibility (NDFD) and acid detergent fiber (ADF) digestibility (ADFD) of both Desmodium ovalifolium and Flemingia macrophylla in growing wether lambs when forage was not treated with polyethylene glycol. Likewise, Barry and Manley (1984) reported decreased hemicellulose and cellulose digestibility of hightannin big trefoil in growing lambs compared to those that received polyethylene glycol treated high-tannin big trefoil. The effect of dietary tannins reducing cell wall digestibility, however, has not been reported in wild browsing ruminants such as WhiteTailed and Mule Deer (Robbins et al., 1987). 
Effects of tannins on nutrient digestibility are not only thought to be the result of interactions of tannins with protein and carbohydrates, but are thought to be the result of the influence of tannins on rumen physiology (Frutos et al., 2004). Primarily, tannins affect rumen physiology as a result of enzyme inhibition and direct effects on growth and morphology of rumen microorganisms. Tannins have also been suggested to affect gas and volatile fatty acid production in the rumen (Kumar and Singh, 1984; Frutos et al., 2004).

Smart et al. (1961) first identified the presence of a sericea lespedeza leaf extract that inhibited enzymatic hydrolysis of cellulose by cellulase. This was later supported by Lyford et al. (1967) who suggested the compound of interest in the sericea lespedeza extract to be a poly-phenolic leucoanthocyanin-like compound of high molecular weight. Likewise, researchers reported that cellulase inhibition was proportional to the concentration of compound of interest in the extract (Lyford et al., 1967). Makkar et al. (1988) reported decreased in vivo activity of urease, carboxymethylcellulase, glutamate dehydrogenase (NADH), glutamate ammonia ligase (glutamine synthetase, and $\gamma$ Glutamyl transferase), as well as alanine aminotransferase (glutamic-pyruvic transaminase) as a result of Quercus incana (bluejack oak) incubation in the rumen. In a subsequent study, Makkar et al. (1988) reported increased inhibition of hydrolytic enzymes (urease, protease, and carboxycellulase), and ammonia-assimilating enzymes (glutamate dehydrogenase NADH, and glutamate dehydrogenase NADPH), as well as alanine aminotransferase (glutamic-pyruvic transaminase) and aspartate aminotransferase (glutamic-oxaloacetic transaminase) as a result of increasing amounts of bluejack oak extract administered to rumen fluid in vitro. This effect, however, was not seen with 
extracts of leaves containing very low tannin-levels (Celtis australis). Likewise, bluejack oak extract had no effect on glutamate ammonia ligase (glutamine synthetase, and $\gamma$ glutamyl transferase) inhibition (Makkar et al., 1988).

Tannins are generally considered inhibitory to the growth and reproduction of microorganisms (Kumar and Singh, 1984; McSweeney et al., 2001; Frutos et al., 2004). Tannins are not only reactive with extracellular enzymes, but may also complex with the cell wall of microorganisms (Frutos et al., 2004), deprive microorganisms of substrates required for microbial growth, as well as inhibit oxidative phosphorylation and electron transport (Scalbert, 1991). Susceptibility of microorganisms (fungi, yeasts, and bacteria) to the toxic effects of tannins has been reviewed by Scalbert (1991). Subsequently, Scalbert (1991) reviewed the capability of microbial adaptation to tannins through synthesis and secretion of tannin-complexing polymers, tannin-resistant enzymes, and small iron-chelating compounds known as siderophores, as well as oxidation, and biodegradation of tannins. Adaptation to these effects, however, is evident in some microorganisms, and may include metabolic modifications such as the secretion of a bacterial cell wall glycocalyx (Frutos et al., 2004), or secretion of tannin-metabolizing enzymes (O’Donovan and Brooker, 2001).

Though the negative effects of high dietary tannin levels on ruminant production have been widely established throughout the literature (Frutos et al., 2004), recent emphasis has been placed on potential benefits to ruminant production associated with utilization of low to moderate levels of dietary tannins. Low to moderate dietary condensed tannin levels of several forage plants have been attributed to increased milk production of cows (Woodward et al., 1999; Wang et al., 1996), as well as wool growth 
(Mcnabb et al., 1993; Wang et al., 1994), ovulation rate (Min et al., 1999; Min et al., 2002), and lambing percentage of sheep (Min et al., 2003), possibly as a result of increased protein utilization.

Protein-tannin complexes are formed as a result of reactions between protein and tannins. Hydrogen bonding between phenolic and ketoimide groups (Haslam, 1974), ionic bonding between the phenolate anion and cationic site of a protein molecule (Loomis, 1974), as well as hydrophobic bonding between aromatic ring structures of phenolic compounds and hydrophobic regions of proteins (Loomis, 1974; Hagerman and Butler, 1980) are thought to be the main interactions responsible for formation of proteintannin complexes (Kumar and Singh, 1984). Formation of this complex, however, is reversible, allowing protein and polyphenols to both be recovered unchanged.

Protein-tannin complex formation is affected by various factors (PerezMaldonado et al., 1995). Altering some conditions, such as $\mathrm{pH}$, result in oxidation of polyphenols to quinone. Quinone may then form a covalent bond with protein (Loomis, 1974; Haslam, 1979). This complex, however, is irreversible (Kumar and Singh, 1984). Protein-tannin complex formation with proanthocyanidins is most efficient at or near $\mathrm{pH}$ of the proteins' isoelectric point (Brown and Wright, 1964; Hagerman and Butler, 1981). This was confirmed by Perez-Maldonado et al. (1995), as bovine serum albumin (BSA) and white clover protein showed maximum interaction with tannic acid at $\mathrm{pH}$ of 4.5 to 5.5 , and 3.5 to 5.5 , respectively. Isoelectric points for both proteins were previously reported at pH 4.9 and 5.5, respectively (Jones and Lyttleton, 1972), falling within the optimal range for protein-tannin complex formation reported by Perez-Maldonado et al. (1995). Rumen $\mathrm{pH}$ values of 4.9 and 5.5, however, would correspond with acute and 
sub-acute cases of ruminal acidosis. Another factor affecting protein-tannin complex formation is the affinity of protein to tannin. A study conducted by Hagerman and Butler (1981) showed the influence of polymer size on protein and polypeptide affinity, with exception to proline-rich protein. Non proline-rich proteins examined with molecular weight of less than 20,000 had relatively low affinities to Sorghum bicolor (sorghum) proanthocyanidins. Researchers attributed the increase in protein-tannin affinity associated with proline-rich peptides and protein to presence of multiple binding sites. Subsequent studies by Hagerman and Butler (1981), and Asquith and Butler (1986) reported selectivity of protein-tannin complex formation in respect to binding affinity, disproving the previously accepted theory of protein-tannin complex non-specificity.

Protein levels provided by rumen microorganisms of moderate producing ruminants are often considered adequate to meet animal requirements. High production situations, such as those of peak-lactation for high producing dairy cattle and rapid growth rates of young growing animals often result in amino acid requirements exceeding those of moderate production levels. These requirements are often met by supplying adequate nitrogen for ruminant microorganisms, and supplying protein that is capable of escaping rumen microbial degradation and being digested in the hind-gut. These proteins are often termed rumen undegradable proteins, or undegradable intake protein. Ruminal degradation is often considered the major factor affecting the utilization of protein by ruminants, and is affected by various factors, including nitrogen solubility, particle size, rate of total DMD, and feeding level (Kellems and Church, 2002). Individual proteins vary widely in their respective rate of degradation in the rumen (Mangan, 1972; Broderick, 1978; Nugent and Mangan, 1981). 
Protection of soluble protein of various oilseed meals and alfalfa from rumen degradation with tannins was first demonstrated by Zelter et al. (1970) with Castanea sativa (european chestnut) tannins. Fraction 1 leaf protein predominates DMI of ruminants consuming fresh, dried, or ensiled forage, and has a high rate of degradation in the rumen (Mangan, 1988). Jones and Mangan (1977) effectively complexed Fraction 1 leaf protein with Onobrychis viciifolia (sainfoin) tannins in vitro. This complex was stable at $\mathrm{pH}$ of 4 to 7 , then readily dissociated at $\mathrm{pH}$ below 4 and above 7 (Jones and Mangan, 1977), indicating stability at typical rumen $\mathrm{pH}$, and dissociation at typical abomassal pH levels. Martin and Martin (1983) reported successful in vitro fraction 1 leaf protein precipitation with oak tannins at a $\mathrm{pH}$ range of 5.6 to 7 , showing the theoretical ability of oak tannin-protein interactions to remain stable at typical rumen $\mathrm{pH}$, followed by dissociation as $\mathrm{pH}$ level falls to a level considered typical of the ruminant abomasum. Likewise, Martin and Martin (1983) precipitated fraction 1 leaf protein with tannins from various other sources. McNabb et al. (1993) confirmed the ability of feeding tanniferous forage to protect protein from proteolysis in the rumen, as well as increase absorption of methionine and cystine.

Nishimuta et al. (1973) reported decreased crude protein (CP) digestibility (CPD) of growing lambs that received tannic acid-treated SBM when compared to non-treated SBM. However, Barry and Manley (1984) reported increased levels of total nitrogen and non-ammonia nitrogen reaching the duodenum of growing lambs that received fresh high-tannin big trefoil when compared to those that received fresh low-tannin big trefoil. Collectively, these two studies indicate decreased total tract protein digestibility, but increased utilization of nitrogen from digested protein as a result of dietary tannins. 
Likewise, a positive correlation was shown between non-ammonia nitrogen flow to the duodenum and Lotus condensed tannin level in sheep (McNabb et al., 1996), but to a greater extent with big trefoil than with birdsfoot trefoil derived condensed tannins (Aerts et al., 1999; Molan et al., 2001). In contrast to these findings, other researchers have reported a decrease in total nitrogen digestibility of wether lambs as a result of tannins from big trefoil (Barry and Manley, 1984), as well as growing beef heifers as a result of tannins from bird resistant sorghum varieties (Streeter et al., 1990). Likewise, Streeter et al. (1990) reported a decrease in non ammonia nitrogen reaching the duodenum of growing beef heifers associated with high-tannin sorghum varieties.

One characteristic of tannins that may be considered detrimental to ruminant nutrition is astringency, or the ability of tannins to precipitate salivary proteins. Astringency causes a reduction in palatability of tannin-containing feedstuffs. This reduction in palatability in-turn contributes to a reduction in voluntary DMI (Kumar and Singh, 1984). This effect was first reported in sheep (Wilkins et al., 1953) and cattle (Donelly, 1954) when animals voluntarily consumed more DM from low-tannin compared to high-tannin sericea lespedeza. This was supported by Barahona et al. (1997) who reported decreased organic matter intake of both Desmodium ovalifolium and Flemingia macrophylla in growing wether lambs when forage was not treated with polyethylene glycol. More recently, Mantz et al. (2009) reported increased DMI and ADG of growing steers that received, as well as selectivity for, fresh-cut sericea lespedeza supplemented with polyethylene glycol-treated grain when compared to steers that received fresh-cut sericea lespedeza supplemented with untreated grain. Mantz et al. 
(2009) suggested the potential for polyethylene glycol treatment of grain supplements to increase DMI and ADG of steers grazing sericea lespedeza in pastures.

An adaptation or tolerance to astringency, however, is apparent in some ruminants based on frequency of exposure to tannins as a normal dietary component. Saliva of browsing ruminants such as the deer contains high levels of a small glycoprotein containing large amounts of proline, glycine, and glutamate/glutamine. This high tanninaffinity protein is absent, however, in the saliva of grazing ruminants such as the cow and sheep (Austin et al., 1989). One theory suggests that mammalian evolution of binding of tannins by salivary proline-rich proteins may be a result of dietary nitrogen limitations arising from a low nitrogen diet (McArthur et al., 1995).

\section{$\underline{\text { Anti-parasitic Effect of Tannins }}$}

Gastrointestinal parasites are an ongoing challenge facing livestock producers throughout the world. Ruminant livestock producers, in particular, may suffer great losses in production, both qualitatively and quantitatively, as a result of un-controlled gastrointestinal parasite infestations. Kimambo et al. (1988) showed that growing lambs persistently infected with Trichostrongylus colubriformis larvae exhibited depressed feed intake, as well as decreased nitrogen and microbial crude protein digestion. Moreover, persistently infected lambs exhibited increased flow of nitrogen to the terminal portion of the ileum, as well as increased plasma nitrogen leakage into the intestine (Kimambo et al. 1988). Traditionally, gastrointestinal parasites have been controlled through the utilization of anthelmintic drugs. Examples of these drugs include, but are not limited to ivermectins, albendazoles, niclosamides, and fenbendazoles. Extensive utilization of 
anthelmintic drugs for treatment or control of gastrointestinal parasites has led to increased drug resistance of these parasites, resulting in the inaffectivity of anthelmintics in such scenarios. Parasite resistance has been noted in goats (Prichard, 1994), sheep (Waller et al., 1996; Leathwick et al., 2001; Pomroy, 2006), and cattle (Pomroy, 2006), indicating a need for alternative control strategies (Min and Hart, 2003). Niezen et al. (1998) showed the affectivity of dietary condensed tannin-containing Hedysarum coronarium (sulla) forage utilization as an alternative method of gastrointestinal parasite control in sheep. Ewe lambs that grazed sulla exhibited lower nematode presence in the abomasum when compared to lambs that grazed forages considered void of or containing low levels of condensed tannins, such as alfalfa, Plantago lanceolata (plantain), as well as a Lolium perenne (perennial ryegrass) and white clover mixture. Likewise, ewes grazing sulla exhibited lower fecal nematode egg counts. Supplementation of growing lambs for duration of one week with condensed tannin containing Calliandra calothyrsus was ineffective at reducing parasite load in growing lambs (Parker and Palmer, 1991), while ten week supplementation with condensed tannin containing quebracho was effective (Butter et al., 2000), indicating the possible need for condensed tannin containing forage to be grazed or supplemented over a long period of time in order to achieve anti-parasitic benefits (Barry et al., 2001).

\section{$\underline{\text { Bloat Reduction with Tannins }}$}

Bloat prevention is potentially an additional effect associated with ruminant feeding programs utilizing tanniferous feedstuffs (Mangan, 1988). Extensive release of soluble proteins into ruminal fluid promotes the formation of a polysaccharide biofilm 
complex that entraps methane gas. Frothy bloat in ruminants occurs as a result of methane gas production in the rumen exceeding the animals' ability to eructate, or release the methane prior to bio-film complex entrapment (Min et al., 2006). Bloat is often associated with legumes, as well as very high quality grasses, and less often associated with cereal grains, brassica forages, and grass hay. Bloat, however, is seldom associated with tropical legumes (Clarke and Reid, 1974).

Min et al. (2005) reported that supplementation with tannins reduced in vitro methane gas production associated with fresh wheat forage. Min et al. (2006) reported a decrease in bloat severity through a reduction of both bio-film and gas production in the rumen, as well as an increase in ADG of stocker steers that received vegetative and reproductive growth from wheat pasture as a result of quebracho tannin supplementation. In this particular study, severity of bloat decreased linearly with increasing quebracho tannin supplementation (Min et al., 2006).

\section{$\underline{\text { Tannin Toxicology }}$}

Hydrolysable tannins hold the potential for toxicity as a result of consumption by ruminants. Hydrolysable tannin degradation by ruminal microorganisms produces pyrogallol; a hepatotoxin and nephrotoxin. Hydrolysable tannin toxicity is most often associated with consumption of high levels of oak leaves as well as leaves from other tanniferous tree legumes. Potential effects of hydrolysable tannins in ruminants include hemorrhagic gastroenteritis, as well as necrosis of the liver and proximal tubules of the kidney (Reed, 1995). 
Very little data and few case study reports are available on oak toxicosis of ruminants. Garg et al. (1992) reported anorexia, severe constipation, and brisket edema of cattle suffering from bluejack oak leaf poisoning as a result of immature leaf consumption. Feces were reported as hard and pelleted, as well as blood- and mucouscoated. Depressed blood hemoglobin, as well as elevated serum bilirubin, urea nitrogen, and creatine were also reported, along with hypocalcaemia, and increased serum aspartate aminotransferase, lactate dehydrogenase, and alkaline phosphatase activity. Likewise, nephro- and heptatotoxicity of cattle was reported. Leaf tannin level was reported as the equivalent of $97.7 \mathrm{mg}$ of tannic acid or $5.8 \mathrm{mg}$ of catechin per gram of dry leaf. Amount of leaf consumed to elicit this effect, however, was not reported. Mortality was reported in seventy percent of affected calves (Garg et al., 1992). Plumley et al. (1998) reported proteinuria, hematuria, glucosuria, as well as blood urea nitrogen and creatinine increases at 3, 4, 5, and 6 days following oak leaf ingestion, respectively. Spier et al. (1987) reported successful treatment of acute oak toxicosis in one calf as a result of diuretic administration and electrolyte/fluid replacement.

Proanthocyanidins, or condensed tannins, are considered non-toxic, as they are not absorbed. Proanthocyanidins, however, are associated with gastrointestinal lesions of the mucosa (Reed, 1995).

\section{Analysis of Phenolic Compounds in Feedstuffs}

Tannins are a very large group of compounds, and are very diverse in their chemical makeup. The basic structures of tannins are phenolic rings that may contain different isomers. Historically, many methods have been introduced in an attempt to 
measure the amount of phenolic compounds present in feedstuffs. However, due to the complex diversity and varying nature of phenolic compounds, no single method has been accepted as a standard protocol for measurement. Generally accepted methods of analysis can be divided into two main groups; colorimetric analysis, and protein binding assays.

Colorimetric analyses are widely utilized as a means of quantifying the total concentration of phenolic compounds within a feedstuff. Of these, redox and functional group assays are the most common. Redox assays are often used to measure the oxidation and reduction potential of phenols within a feedstuff to form a complex with a metal. Generally, these assays are used to determine the quantity of total phenolic compounds (TPC) within a feedstuff, and are ineffective at phenolic classification, as they are not specific to tannin or non-tannin phenolics (Schofield et al., 2001; Hagerman and Butler, 1989). Folin-Denis (Folin and Denis, 1915) and Prussian blue (PBA; Price and Butler, 1977) assays are the two most common redox assays used for determining TPC (Schofield et al., 2001). Limitations of these assays include interference with some proteins, purine bases, as well as readily oxidizable compounds. Prussian blue assays are less susceptible to interference with protein, and therefore are used more often than FolinDenis assays (Hagerman and Butler, 1989). Authors have noted that a limitation of the PBA includes specificity of incubation time, as increases in incubation time have shown increases in optical density (Schofield et al., 2001, Price and Butler, 1977). Functional group assays, such as the Vanillin-HCl (Price et al., 1978) and acid-butanol assays are often utilized to quantify specific phenolic compounds, such as proanthocyanidins (Hagerman and Butler, 1989), but are ineffective at detecting non-condensed tannins. 
Protein precipitating assays (PPA) are often utilized to determine the protein precipitating capability (PPC) of phenolic compounds within a feedstuff, as this is a general characteristic of phenolic compounds that is of importance to ruminant nutrition. Of these, the most common assays utilize BSA (Hagerman and Butler, 1978), $\beta$ glucosidase (Goldstein and Swain, 1963), or hemoglobin (Bate-Smith, 1973) as protein sources (Martin and Martin, 1982). Limitations to all methods exist (Makkar, 1989), though the methods outlined by Hagerman and Butler (1978), utilizing BSA, are widely utilized due to the ease in which the procedure may be performed, reproducibility, and non-specificity of results to phenolic composition.

\section{Inactivation of Tannins in Feedstuffs}

The utilization of tree leaves as a dietary source of nutrients may pose some issues in regards to tannin concentration. Likewise, if leaves are to be incorporated into complete feeds, some common manufacturing practices may affect ultimate tannin concentration and activity. Traditionally, tannins in crops and forages have been credited with agronomic benefits such as decreased predation, as well as resistance to pathogens, insects (Kumar and Singh, 1984), and weather (Harris and Burns, 1970). Potential of tannin removal from feedstuffs may lead to the loss of agronomic benefits associated with tannins in crops and forages. As a result, methods of tannin inactivation have been researched (Kumar and Singh, 1984) and may be beneficial for other high tannin feeds.

Conflicting results on the effectiveness of water treatment to extract tannins of sorghum grain have been reported by various authors. Reichert et al. (1980) reported a 39.4 percent reduction in the tannin content of whole grain sorghum of a bird-resistant 
variety as a result of soaking in water for duration of two days. Under similar conditions, tannin content was reduced to 8.3 percent of the original level after soaking for duration of nine days (Reichert et al., 1980). Price et al. (1980), however, found boiling ineffective at improving the nutritional quality of a similar type of whole grain sorghum.

Various alkali solutions have effectively been utilized to extract tannins from bird resistant whole grain sorghum (Kumar and Singh, 1984) with success to a much greater extent than that of water (Chavan et al., 1979). Chavan et al. (1979) found that extraction of bird resistant whole sorghum grain with sodium hydroxide $(\mathrm{NaOH})$ and potassium hydroxide $(\mathrm{KOH})$ for twenty four hours reduced tannin content by 75 to 85 percent. Sodium carbonate $\left(\mathrm{Na}_{2} \mathrm{CO}_{3}\right)$ removed tannins to the same extent under similar conditions. Subsequently, researchers found that similar treatment at $100{ }^{\circ} \mathrm{C}$ increased the rate of tannin extraction, in turn reducing the time required to leach the same amount of tannins from the sorghum grain (Chavan et al., 1979). Alkali extraction with $\mathrm{NaOH}$ and $\mathrm{KOH}$ was also found to increase in vitro protein digestibility (Chavan et al., 1979) and DMD in rats (Reichert, 1980) of bird resistant whole grain sorghum. Likewise, Price et al. (1978) reported an increase in bird resistant whole grain sorghum nutritional quality as a result of extraction with ammonia $\left(\mathrm{NH}_{3}\right)$. However, it should be noted that alkali treatment may result in a loss of DM through leaching of soluble nutrients (Kumar and Singh, 1984).

\section{Feed Processing}

The most probable use of tree leaves as a dietary ingredient would be through their utilization as a component of complete feeds such that nutrient composition and 
feed formulation with leaves can be highly controlled and selective feeding may be avoided. In this scenario, leaves would be subjected to common processing methods that ultimately may affect their composition. Many grain and feed processing methods have been utilized by producers in an effort to improve grain and feed utilization by ruminant livestock species, in turn reducing a major cost associated with production. Grain processing methods can be broken into two major classifications; cold and hot. These classifications represent the presence or absence of supplemental heat during processing. Cold processing methods include, but are not limited to rolling, cracking, grinding, soaking, reconstituting, high moisture ensiling, and high moisture acid preservation. Hot processing methods include, but are not limited to steam-rolling, steam-flaking, and pelleting (Kellems and Church, 2002).

Cold processing methods commonly utilized for dry grain processing without the addition of supplemental moisture include rolling, cracking, and grinding. These processing methods result in a reduction of feedstuff particle size, with the finished particle size dependant upon processing method, as well as equipment utilized for a given processing method. Grinding is considered an effective method utilized to reduce the particle size of not only grains, but roughages such as alfalfa, sugar beet pulp, and longstem hay as well. Particle size reduction results in an increase in feedstuff surface area. This increase in surface area increases the opportunity for feedstuff contact with digestive secretions, as well as interaction with rumen microorganisms (Kellems and Church, 2002). Galyean et al. (1981) showed an inverse relationship between DMD, as well as starch disappearance, and corn/sorghum particle size. The extent of this effect however, 
differs between feedstuffs, as well as species in which the feedstuff is fed (Theurer, 1986).

Galyean et al. (1979) showed that grinding increased ruminal DMD and OMD, intestinal DMD and OMD, as well as ruminal starch digestion of steers that received corn-based finishing feedlot rations when compared to respective values of steers that received whole shelled corn-based finishing feedlot rations. However, no differences were reported between fine $(3.18 \mathrm{~mm}$ screen $)$, medium ( $4.76 \mathrm{~mm}$ screen $)$, and coarse (7.94 $\mathrm{mm}$ ) treatments. Grinding had no effect on DMI, as well as ruminal $\mathrm{pH}$ or passage rate, while it decreased fecal pH (Galyean et al., 1979). Turgeon et al. (1983) showed that steers fed a 50:50 mixture of whole shelled corn and cracked corn gained more efficiently than steers fed whole shelled corn or cracked corn as the sole source of corn in the rations. In this experiment, steers fed a mixture of whole shelled and cracked corn, as well as steers fed a mixture of whole shelled and ground corn exhibited faster rates of gain when compared to steers fed diets that contained whole shelled corn as the sole source of corn in the ration (Turgeon et al., 1983).

This effect, however, does not occur in all grains. An extensive review of the effect of grain source and grain processing on performance of feedlot cattle by Owens et al. (1997) showed increased DMI and FE for cattle that received dry rolled corn compared to whole shelled corn, but no difference in DMI or FE for cattle that received dry-rolled barley compared to whole barley. Mathison (1996) reported a reduction in DMI as well as feed efficiency of finishing steers that received ground barley compared to steers that received dry rolled barley. 
Steam-flaking is a hot feed processing method that involves steam conditioning grain until the grain reaches a moisture level of eighteen to twenty two percent, followed by rolling between corrugated rollers, producing a flake. This process fractures the cell wall, allowing the starch granule to be ruptured and gelatinized (Kellems and Church, 2002; Speetjens, 2002). Steam-flaking is considered the primary grain processing method utilized for finishing feedlot rations throughout the United States (Vasconcelos and Galyean, 2007). Cole et al. (1976) showed that steam-flaking corn did not affect DMI of finishing feedlot steers, but increased rumen and total tract DMD of finishing feedlot diets when compared to dry rolling corn. In addition, Galyean et al. (1976) found no effect of corn processing method on ruminal $\mathrm{pH}$ or DMI. Rate of ruminal DMD, however, was higher for steers that received steam flaked corn-based diets when compared to steers that received dry rolled corn-based diets (Galyean et al., 1976). Ramirez et al. (1985) found that steam-flaking corn increased FE and ADG of finishing feedlot steers. Similarly to cold processing of barley, steam-flaking barley has shown no improvement of feed efficiency in finishing feedlot cattle when compared to dry-rolling. In contrast, an increase in palatability was shown as steam-flaking increased DMI of finishing feedlot steers (Hale et al., 1966).

No benefit as a result of cold feed processing alone has been reported on finishing lamb performance. Hejazi et al. (1999) reported decreased DMD, OMD, and NDFD of ground corn-based finishing feedlot lamb diets when compared to whole shelled cornbased finishing feedlot lamb diets. Lambs that received dry-rolled wheat-based finishing diets maintained similar FE, however exhibited lower ADG when compared to lambs that received whole wheat-based finishing diets. Alternatively, lambs that received rolled 
barley- or cracked corn-based finishing diets exhibited increased FE, however exhibited lower ADG when compared to lambs that received whole barley- and whole shelled cornbased finishing diets (Stanton and LeValley, 2006). Cold processing grains for finishing feedlot lamb diets shows no advantage over utilization of whole grains (Umberger, 2009; Lardy, 1999), as well as no benefit of cost-effectiveness when factoring additional expense associated with processing.

Pelleting is an energy-intensive process that begins with introduction of blended and steam-conditioned feed or individual ingredients into a pelleting chamber by gravity, centrifugal force, and mechanical deflectors. Pressure from rotating dies and counterrotating rollers force the fallen feed through perforations in the die. This compresses the feed or individual ingredient in the die perforations (Robinson, 1976), forming an agglomerated feed or individual ingredient commonly used for animal feed, known as a pellet (ASAE, 2007). Adjustable knives cut pellets at a specified length as they are extruded through the rotating die. Pellets are then cooled at and dried to approximately $15^{\circ} \mathrm{F}$ and 88 to 90 percent $\mathrm{DM}$, respectively, prior to bagging, binning, and/or transportation (Robinson, 1976).

Feeding diets in pellet form is generally recognized as a means of increasing swine and poultry performance, as well as decreasing a major cost associated with production; feed. A review of pelleting by Behnke (1994) attributed decreased costs associated with production of swine and poultry that received pelleted diets to decreased selective feeding, ingredient segregation, and time and energy expenditure associated with feed prehension, as well as increased destruction of pathogenic organisms, palatability, and digestibility. Decreased costs associated with production are a direct 
result of increased ADG and FE, as well as decreased feed wastage. This was first shown by Hussar and Robblee (1962) as an increase in broiler performance as a result of feed form when broilers that received pelleted diets expressed an increase in FE. This was later confirmed by Hull et al. (1968). Similarly, this effect was seen in turkeys (Proudfoot and Hulan, 1982). More recently, feeding pelleted diets, regardless of quality, has been attributed to increased carcass weight of broilers when compared to feeding a meal form of the same diet (Lilly et al., 2009).

Similar to poultry, the effectiveness of pelleting as a means of increasing growth and finishing performance of swine has long been understood. This was first reported as an increase in FE without affecting ADG or DMI of growing pigs, as a result of feeding pelleted diets (Jensen and Becker, 1965). Increased FE of growing pigs that received diets in pellet form compared to diets in meal form was later supported by Hanke et al. (1972). In contrast to findings of Jensen and Becker (1965), Hanke et al. (1972) reported an increase in ADG as well. Baird (1973) first reported increased FE and ADG, along with decreased DMI of finishing pigs that received diets in pellet form compared to meal form. This was more recently supported by Wondra et al. (1995). Skoch et al. (1983a; 1983b) supported the increase in FE of finishing pigs, however reported no effect on ADG and DMI as a result of feeding diets in pellet compared to meal forms. As a result of various aspects of improvement in performance, the vast majority of monogastric livestock feed in the United States is marketed or fed in pellet or crumble form.

In contrast to much of the data available for swine and poultry, there appears to be limited benefit of pelleting complete diets for cattle. Lassiter et al. (1955) found no difference in DMI or FE of dairy calves that received pelleted or ground starter rations. 
Likewise, Weir et al. (1959) showed no benefit of pelleting a sixty percent concentrate diet to ADG, DMI, or FE. Alternatively, Blosser and Shaw (1959) reported that lactating cows that received a pelleted concentrate portion of the diet exhibited a higher feed consumption rate than cows that received a ground concentrate portion of the diet. Researchers found no effect of pelleting the roughage source (peanut hulls) in finishing steer diets on DMI, ADG, and FE. However, incidence of liver abscess was significantly higher for steers that received pelleted (16 of 27) or ground (14 of 25) peanut hulls as a roughage source when compared to steers that received whole ( 1 of 25) peanut hulls (Utley et al., 1973). Dinius et al. (1978) found no benefit to pelleting alfalfa-based diets for forage-finishing beef steers.

Lack of a benefit associated with feed processing for finishing feedlot cattle, however, differs greatly from benefits associated with pelleting finishing feedlot lamb diets. Long et al. (1955) reported increased DMD of pelleted complete diets fed to finishing lambs compared to ground diets of identical ingredient composition. Meyer et al. (1959) reported no effect of feeding pure pelleted alfalfa hay on OMD of finishing lambs when compared to chopped alfalfa hay. Esplin (1957) reported an increase in ADG, with no difference in FE of finishing lambs that received pelleted rations when compared to finishing lambs that received ground rations, and attributed this effect to an increase in DMI. This was supported with similar findings by Weir et al. (1959), Meyer et al. (1959), and Fontenot and Hopkins (1965). Hatfield et al. (1997) reported similar results after comparing a fifteen percent inclusion of pelleted to ground roughage source (alfalfa) in barley-based finishing lamb diets. Meyer et al. (1959) attributed this increase in DMI to an increased passage rate of pelleted feeds, which was later supported by 
Thomson's (1972) review of the relationship between dietary physical form and rumen fermentation. Likewise, Bernard et al. (2000) reported an inverse correlation between pelleted:ground orchardgrass hay and rumen retention time.

Pelleting is often utilized to reduce dustiness in, improve handling, storage, and feeding characteristics of, as well as prohibit selective feeding and bunk-sorting of ruminants (Robinson, 1976). Pelleting complete feeds for ruminants may increase performance when undesirable feeds, such as low quality forages or other low quality roughages are a large component of the diet. Pelleting certain ingredients such as wheat middlings, $\mathrm{SBH}$, and alfalfa meal, or ingredient mixtures, is often beneficial as pellets mix well with processed or whole grains to form complete and textured feeds (Kellems and Church, 2002).

Pellet quality has been shown to affect performance of both broilers and turkeys. Broilers that received reground pellets exhibited decreased FE when compared to broilers that received a meal form of the same diet (Hull et al., 1968). Likewise, Moran (1989) showed a decrease in performance when turkeys were provided reground pellets when compared to a meal form of the same diet. Proudfoot and Hulan (1982) showed a negative correlation between level of fines in pelleted diets and growing turkey performance. Broilers that received a high quality ( 90 percent pellets, 10 percent fines) pelleted diet were found to yield higher carcass weights when compared to broilers that received a low quality (30 percent pellets, 70 percent fines) pelleted diet (Lilly et al., 2009). Research addressing the effect of pellet quality of swine diets is scarce. As reported by Behnke (2001), observation of a failure in improvement of growing and finishing performance as a result of poor quality pellets has led to an increase in attention 
to pellet quality throughout much of integrated pork production. Likewise, very little information on the effect of pellet quality of ruminant diets has been reported. However, various factors have been reported to affect pellet quality, including feed formulation, ingredient particle size, and conditioning properties (Behnke, 2001), as well as die specifications (Buchanan et al., 2008), pellet mill operating speeds, and drying/cooling of pellets (Gehring, 2009).

Pelleting is of little benefit to animal performance if pellets are unable to maintain integrity throughout handling, storage, and feeding. Potential protein-tannin interactions associated with tanniferous feedstuffs may affect pellet quality. Likewise, feed formulation often affects pellet quality directly as a result of nutrient interactions during the pelleting process. Authors have not only reported that altering dietary level of starch affects pellet quality, but have also reported similar effects as a result of increasing the protein level of diets (Winowiski, 1988; Briggs et al., 1999; Buchanan et al., 2008). Likewise, Gehring et al. (2009) reported effects of protein functionality to pellet quality. Recently, researchers found a positive correlation between increasing isoelectric solubilization/precipitation recovered whole fish muscle protein inclusion level and pellet quality (Gehring et al., 2009). Prior processing of ingredients has also been suggested to affect pellet quality (Thomas et al., 1998). Great variance exists in pellet binding capability between, as well as within individual feedstuffs, and has been reviewed extensively by Thomas et al. (1998). Other factors, however, may reduce these effects. Authors have reported potential for die lubrication (Jones et al., 1995; Cutlip et al., 2008) as well as nutrient coating (Zimonja et al., 2007) as a result of mixer-added fat (Gehring et al., 2009). 
Adverse interactions among factors affecting pellet quality may exist, as factors that may affect pellet quality may inversely affect animal performance as a result of reduction in nutrient quality and exogenous enzyme activity (Gehring et al., 2009). Supporting this theory, mixer-added fat has been reported to decrease pellet quality (Salmon, 1985; Cavalcanti and Behnke, 2005a; 2005b).

Moisture addition at the mixer has been reported by various authors to decrease electrical energy usage while increasing pellet quality and feed mill production rate (Greer and Fairchild, 1999; Muirhead, 1999). This was later supported by Moritz et al. (2002 and 2003) and may be an effective method of optimizing pellet durability and efficiency of the pelleting process. Likewise, increased pellet durability has been reported as a result of low moisture/mold inhibitor inclusion at the mixer in commercial mills (Hott, 2007).

Skoch et al. (1983a; 1983b) reported increased pellet durability as well as decreased damage to starch as a result of steam conditioning poultry diets. Likewise, authors have reported additional benefits associated with steam conditioning, including increased rate of feed production, as well as decreased electrical energy usage as a result of die lubrication (Skoch et al., 1981; Skoch et al., 1983a and 1983b). Nutrient quality, however, may be sacrificed as a result of conditioning temperatures exceeding $80-95^{\circ} \mathrm{C}$ (Gehring, 2009). Effectiveness of steam conditioning may also be dependant upon moisture diffusion level of various ingredients, as well as mixing uniformity during the conditioning process (Briggs et al., 1999). Level of steam conditioning required to achieve a particular temperature is also affected by ambient feed mill temperature, as well as feed temperature prior to conditioning (Cutlip et al., 2008; Briggs et al., 1999). 


\section{Induced Molting of Laying Hens}

Another potential use for dietary incorporation of leaf meal is in induced molting programs for laying hens. Molting programs are very important to productivity and profitability of commercial egg production. Molting is essential to optimizing productivity of pullets and laying hens. Without incorporation of molting, pullets remain in production for and are slaughtered after only one laying cycle. Molting results in cessation of the laying cycle for a minimum duration of two weeks as a result of nutrient restriction along with decreasing simulated day length, or light exposure. During molting, female reproductive tracts are rejuvenated, in turn resulting in increased productivity (Bell, 2003). Induced molting has been found to effectively increase egg quality by enhancing quality of the albumen and shell when compared to eggs from nonmolted hens at a similar stage of production (Keshavarz and Quimby, 2002), as well as increasing egg weight, candle grade, shell thickness, specific gravity, and shell texture (Bell, 2003). Induced molting has also been found to have no effect on feed consumption throughout following laying cycles (Bell, 2003).

Traditionally, feed withdrawal until achieving average hen body weight reductions of twenty five to thirty five percent has been used as the preferred method of molt induction in laying hens (Ruszler, 1998). Animal welfare, along with food safety issues associated with feed withdrawal have resulted in the evaluation and utilization of a number of non-withdrawal molting programs. The two major classifications of nonwithdrawal molting programs include utilization of diets low in nutrient availability to the hen, as well as the utilization of feed additives that inhibit egg production (Bell, 2003). Feedstuffs such as wheat middlings (Seo et al., 2001; Biggs et al., 2004), cottonseed meal 
(Davis et al., 2002), SBH (Koelkebeck et al., 2006), corn gluten feed (Biggs et al., 2004) and alfalfa (Landers et al., 2005a; Landers et al., 2005b; Donalson et al., 2005) have proven effective as large components of non-withdrawal molting diets. Alfalfa inclusion rates of up to one hundred percent have been shown to effectively induce molt in laying hens after eight days (Donalson et al., 2005). Likewise, Landers et al. (2005a) showed that alfalfa could be provided ad libitum to laying hens in order to effectively induce molt.

Based on the above literature review there appears to be potential for utilization of leaf meal as a dietary constituent after nutrient and chemical composition is known. Once unique nutrient and chemical constituents of leaf meal are known, proper utilization and recommendations can be made to potential users. 


\section{Materials and Methods}

\section{General Leaf Harvest and Preparation}

Fall dropped Quercus alba (white oak) and Liriodendron tulipifera (tulip

poplar) leaves were collected daily at the Appalachian Farming Systems Research Center in Beaver, WV by the USDA-ARS. Collection began September 15, 2007, and ended November 15, 2007. Collected leaves were transferred to 23" x 40" burlap bags. Burlap bags were filled without compressing leaves within the bag. Burlap bags were then transported to a walk-in drying room located at the West Virginia University (WVU) Agronomy Farm in Morgantown, WV, and dried at $35^{\circ} \mathrm{C}$ for a minimum duration of seven days. Dry leaves were transported to the pilot feed mill at the WVU Animal Science Farm in Morgantown, WV. There, leaves were ground through a 3.175 mm pore screen using a hammer mill. Ground leaves were then transported, by auger, to a single screw vertical mixer, in synchrony with the hammer mill, and thoroughly mixed throughout the duration of grinding, as well as an additional ten minutes following completion of grinding. Leaves were then transported to 23 " $\mathrm{x} 40$ " polypropylene feed bags (approximately $9 \mathrm{~kg}$ per bag) and stored at ambient temperature as leaf meal.

\section{Leaf Meal Chemical Composition}

Proximate Analysis and Fiber Determination: Samples of both white oak leaf meal (WOLM) and tulip poplar leaf meal (TPLM) were collected. Representative samples were produced by removing three $0.5 \mathrm{~kg}$ samples per bag, including samples from the lower, middle, and upper portions of the bag, for all bags, and hand-mixing, 
prior to removal of a $1 \mathrm{~kg}$ sample for analysis. Samples were analyzed to determine DM, $\mathrm{OM}$, and CP, utilizing procedures outlined by the AOAC International (2000). Soluble crude protein (SCP) was determined utilizing procedures described by Licitra et al. (1996). Neutral detergent fiber, ADF, and acid detergent lignin (ADL) were determined using procedures described by ANKOM Technology (2006). Crude protein bound to NDF (CPNDF), as well as CP bound to ADF (CPADF) were determined by performing the Kjeldahl procedure on NDF and ADF fractions.

Phenol Analysis: White oak and tulip poplar leaf meal samples were analyzed to determine quantity of TPC using a modification of the PBA of Price and Butler (1977). Leaf meal samples were ground thoroughly with a mortar and pestle. Phenolic compounds were extracted from $300 \mathrm{mg}$ leaf meal samples. Samples were mixed with 15 $\mathrm{mL}$ of methanol, and shaken vigorously in glass, screw-topped, Teflon-lined, capped test tubes for duration of 60 seconds. Samples were then filtered through a suctioned Buchner funnel. Each sample was extracted twice. After extraction, liquid filtrate was mixed with $250 \mathrm{~mL} \mathrm{H}_{2} \mathrm{O}$. Aliquots of $1.5 \mathrm{~mL}$ of liquid filtrate and $\mathrm{H}_{2} \mathrm{O}$ solution were analyzed within one hour of extraction. Reagent A $(100 \mathrm{~mL})$ was produced by addition of $1.6621 \mathrm{~g} \mathrm{FeCl}_{3}$ to a $100 \mathrm{~mL}$ volumetric flask, followed by addition of $0.1 \mathrm{~N} \mathrm{HCl}$. Reagent $\mathrm{B}(100 \mathrm{~mL})$ was produced by addition of $0.2634 \mathrm{~g} \mathrm{~K}{ }_{3} \mathrm{Fe}(\mathrm{CN})_{6}$ to a $100 \mathrm{~mL}$ volumetric flask, followed by addition of distilled $\mathrm{H}_{2} \mathrm{O}$. Standard catechin solution (100 $\mathrm{mL}$ ) was produced by addition of $100 \mathrm{mg}$ catechin to $10 \mathrm{~mL} \mathrm{EtOH}$ in a $100 \mathrm{~mL}$ volumetric flask, followed by addition of distilled $\mathrm{H}_{2} \mathrm{O}$. Standards were produced by addition of $0.00,0.25,0.50,0.75,1.00$, and $1.25 \mathrm{~mL}$ standard catechin solution to glass 
vials, followed by addition of 4.00, 3.75, 3.50, 3.25, 3.00, and $2.75 \mathrm{~mL}$ distilled $\mathrm{H}_{2} \mathrm{O}$, respectively. Reagent A ( $80 \mu \mathrm{L})$ was added to the extract, followed by timed addition of Reagent B $(80 \mu \mathrm{L})$. Samples were then mixed, followed by transfer $(200 \mu \mathrm{L})$ to designated wells of a 96-well microplate. Samples were allowed to incubate in wells for ten minutes prior to being read at $720 \mathrm{~nm}$ with a spectrophotometer. Blanks were included, following all procedures with the exception of leaf addition during extraction. Optical density (OD), after subtraction of an average of blank values, was used in the following equation to calculate catechin equivalents (CE) per gram of sample:

$$
C E \text { of Analyzed Sample }=\left(\left(\frac{(O D \quad \text { Standard Intercept })}{\text { Slope }}\right) * \text { Dilution Factor }\right) .
$$

Catechin equivalents per gram of DM extracted sample weight were calculated using the following equation:

$$
C E \text { of DM Sample WT }=\left(\frac{\text { 'E of Analyzed Sample }}{D M \text { Sarnple } W T}\right) .
$$

Catechin equivalents per gram of DM extracted sample weight was then multiplied by 100 , and expressed as equivalent phenol content of $\mathrm{mg}$ of catechin per $100 \mathrm{mg}$ of extracted sample.

White oak and tulip poplar leaf meal was also analyzed to determine the PPC of compounds present within WOLM and TPLM utilizing a procedure modified from both the PPA of Hagerman and Butler (1978) and Harbertson and Adams (unpublished). 
Buffer A (100 mL) was produced by adding $1.14 \mathrm{~mL}$ acetic acid (glacial) to $0.9935 \mathrm{~g}$ $\mathrm{NaCl}$ in a $100 \mathrm{~mL}$ volumetric flask, followed by addition of distilled $\mathrm{H}_{2} \mathrm{O}$. Buffer A was then adjusted to a $\mathrm{pH}$ of 4.9 with $2.0 \mathrm{~N} \mathrm{NaOH}$. Buffer $\mathrm{B}(100 \mathrm{~mL})$ was produced by addition of $12 \mathrm{~mL} \mathrm{EtOH}$ to $0.5000 \mathrm{~g} \mathrm{KHC}_{4} \mathrm{H}_{4} \mathrm{O}_{6}$ to a $100 \mathrm{~mL}$ volumetric flask, followed by addition of distilled $\mathrm{H}_{2} \mathrm{O}$. Buffer $\mathrm{B}$ was then adjusted to a $\mathrm{pH}$ of 3.3 with $0.1 \mathrm{~N} \mathrm{HCl}$. Buffer $\mathrm{C}(100 \mathrm{~mL})$ was produced by addition of $5 \mathrm{~mL}\left(\mathrm{HOCH}_{2} \mathrm{CH}_{2}\right)_{3} \mathrm{~N}$ to $5 \mathrm{~g}$ $\mathrm{CH}_{3}\left(\mathrm{CH}_{2}\right)_{10} \mathrm{CH}_{2} \mathrm{OSO}_{3} \mathrm{Na}$, followed by addition of distilled $\mathrm{H}_{2} \mathrm{O}$. Buffer $\mathrm{C}$ was then adjusted to a pH of 9.4 with $0.1 \mathrm{~N} \mathrm{HCl}$. Protein solution $(100 \mathrm{~mL})$ was produced by addition of $100 \mathrm{mg}$ BSA (Fraction V) to a $100 \mathrm{~mL}$ volumetric flask, followed by addition of buffer A. Reagent A ( $100 \mathrm{~mL})$ was produced by addition of $1.6221 \mathrm{~g} \mathrm{FeCl}_{3}$ to a 100 $\mathrm{mL}$ volumetric flask, followed by addition of distilled $\mathrm{H}_{2} \mathrm{O}$. Standard catechin solution $(100 \mathrm{~mL})$ was produced by addition of $100 \mathrm{mg}$ of Catechin to $10 \mathrm{~mL}$ of EtOH in a volumetric flask, followed by addition of distilled $\mathrm{H}_{2} \mathrm{O}$. All buffers, reagents, and standards were mixed by thorough swirling, unless otherwise stated. Standards were produced by addition of $0,50,100,150,200,250$, and $300 \mu \mathrm{L}$ standard catechin solution to glass vials, followed by addition of $875,825,775,725,675,625$, and $575 \mu \mathrm{L}$ of buffer $\mathrm{C}$, respectively. White oak and tulip poplar leaf meal samples were ground thoroughly with a mortar and pestle. Samples $(500 \mathrm{mg})$ were extracted by addition of $12.5 \mathrm{~mL}$ $\mathrm{MeOH}$ to samples in centrifuge tubes, followed by constant mixing in a shaker at 525 rpm for duration of fifteen minutes. Samples were then centrifuged at $8,000 \mathrm{x} g$ for ten minutes to separate the liquid extract from respective leaf meal samples. Liquid extract was pipetted from the sample, and analyzed within eight hours. Liquid samples were diluted to $50 \mathrm{~mL}$ in individual volumetric flasks with buffer B. Protein solution $(1 \mathrm{~mL})$ 
was pipetted to microfuge tubes, followed by addition of buffer B diluted sample (500 $\mu \mathrm{L})$. Samples were slowly agitated throughout incubation for duration of fifteen to thirty minutes. Samples were centrifuged $(14,000 \mathrm{x}$ g) for five minutes. Supernatant was then poured off, while retaining the precipitate in the microfuge tube. Buffer $\mathrm{A}(250 \mu \mathrm{L})$ was slowly added to the precipitate as the first rinse, recentrifuged $(14,000 \mathrm{xg})$ for one minute, and the supernatant was then poured off, while retaining the precipitate in the microfuge tube. Buffer A $(250 \mu \mathrm{L})$ was slowly added to the precipitate as the second rinse, recentrifuged $(14,000 \mathrm{xg})$ for one minute, and the supernatant was then poured off carefully, while retaining the precipitate in the microfuge tube. Buffer $\mathrm{C}(875 \mu \mathrm{L})$ was added to the remaining precipitate, followed by thorough mixing with a vortex. Samples were then allowed to incubate for ten minutes, followed by transportation $(200 \mu \mathrm{L})$ to designated microplate wells. Absorbance was read at $510 \mathrm{~nm}$ utilizing a spectrophotometer. Reagent A $(125 \mu \mathrm{L})$ was then added to replicate samples in microfuge tubes, followed by thorough mixing with a vortex. Samples were allowed to incubate for ten minutes prior to being transferred $(200 \mu \mathrm{L})$ to designated microplate wells. Absorbance was then calculated under identical settings by the same spectrophotometer. Optical density was corrected by subtraction of blank values $(0 \mu \mathrm{L}$ standard catechin solution wells). Corrected optical density (COD) was used in the following equation to calculate $\mathrm{CE}$ of the analyzed samples:

$G E$ of Analyzed Sample $=\left(\left(\frac{(\text { fon }- \text { Standard Intercifpt })}{\text { Slope }}\right) *\right.$ Dtlutton F'actor $)$. 
Catechin equivalents per gram of DM extracted sample weight were calculated using the following equation:

$$
C E \text { of } D M \text { Sample WT }=\left(\frac{C E \text { of Analyzed Sample }}{D M \text { Sample } W T}\right) \text {. }
$$

Catechin equivalents per gram of DM extracted sample weight was then multiplied by 100 and expressed as equivalent PPC of mg catechin per $100 \mathrm{mg}$ of extracted sample.

$\underline{\text { In situ Ruminal Dry Matter Digestibility of White Oak and Tulip Poplar Leaf Meals }}$ In situ ruminal DMD of WOLM and TPLM was determined using two nonlactating ruminally cannulated Holstein dairy cows. Cows received a corn silage- and grass haylage-based diet and were allowed to graze a mixed grass and legume summer pasture at the WVU Animal Science Farm in Morgantown, WV throughout the duration of the experiment. Impulse sealed polyester ANKOM rumen In situ bags $(10$ x $20 \mathrm{~cm}$; pore size of $50 \pm 15$ microns) containing $6.0015 \pm 0.0015$ grams of WOLM or TPLM were incubated in the rumen of cows, in triplicate, via a switch-back design for $0,1,2,4$, $8,12,24,48$, and 72 hours. Bags were allowed to soak in ambient temperature water for two minutes before placement in the rumen at $72,48,24,12,8,4,2$, and 1 hours prior to removal. Bags were incubated together in a single polyester mesh bag, and removed at the same time. Upon removal, bags were rinsed until clear rinse water was obtained, and dried in a $50{ }^{\circ} \mathrm{C}$ forced air oven for 3 days. Zero hour incubation bags were not incubated in the rumen, but were subjected to the same soaking, handling, rinsing, and drying procedures as incubated bags. Percentage of undigested DM was determined by 
dividing dry sample weight post incubation by dry sample weight prior to incubation, and multiplying by one hundred. Percentage DMD was determined by subtracting percentage of undigested DM from one hundred.

$\underline{\text { Feed Manufacture and Growing Lamb Metabolism }}$

Experimental Design: Six crossbred wether lambs with an initial BW of $28.69 \pm$ $0.57 \mathrm{~kg}$ were utilized in two subsequent studies to determine the nutrient digestibility of growing lamb diets containing low and high inclusion rates of WOLM and TPLM.

Lambs were randomly assigned to one of two studies; WOLM or TPLM. Once assigned to a particular study, lambs within that study were randomly assigned to one of two dietary treatments, including low white oak leaf meal (LOLM) and low tulip poplar leaf meal (LPLM) inclusion (ten percent dietary DM), high white oak leaf meal (HOLM) and high tulip poplar leaf meal (HPLM) inclusion (twenty percent dietary DM), or a basal control diet (no dietary leaf meal inclusion; BA). Lambs were housed in individual stainless steel metabolism crates at the WVU Animal Science Farm in Morgantown, WV for individual and separate collection of fecal and urinary output throughout the duration of the experiment. A Latin Square experimental design was utilized throughout the experiment. The experiment lasted for duration of thirty days, utilizing ten day periods. Lambs were adapted to a dietary treatment for a minimum of seven consecutive days prior to a urinary and fecal collection period of three consecutive days. At the conclusion of a collection period, lambs were re-assigned to a different treatment. 


\section{Experimental Diet Formulation and Feed Manufacture}

Diets were formulated to meet a $\mathrm{CP}$ of eighteen percent and a minimum calcium to phosphorus ratio of $1.45: 1$. Nutrient constraints and ingredient inclusions were calculated and reported on a percentage DM basis. Ground corn and SBM were adjusted to maintain an average formulated dietary CP percentage of eighteen. White oak or tulip poplar leaf meal was utilized as a replacement for SBH in experimental treatments. Basal control diets contained a SBH inclusion level of twenty percent of total dietary DM. Low white oak leaf meal and LPLM diets contained a SBH inclusion level of ten percent of total dietary DM, and utilized respective leaf meals to replace fifty percent of the dietary DM from SBH. High white oak leaf meal and HPLM diets contained no SBH, and utilized respective leaf meals to replace one hundred percent of the dietary DM from SBH. Diet formulations are shown in Table 1. Whole oats, alfalfa cubes, beet pulp pellets, soybean oil, vitamin premix, mineral premix, and salt inclusions were constant for all diets at $15,15,14,4,0.5,0.5$, and 0.5 percent of dietary DM, respectively. Mineral premix utilized in treatment and control diets was identical, and contained a minimum of $19 \% \mathrm{Ca}, 3 \% \mathrm{P}, 2.5 \% \mathrm{Mg}, 3 \% \mathrm{~S}, 2.4 \% \mathrm{~K}, 15 \% \mathrm{NaCl}, 0.24 \% \mathrm{Fe}, 0.27 \%$ Zn, $0.24 \%$ Mn, $0.004 \%$ I, $0.003 \%$ Co, and $0.0024 \%$ Se on a DM basis. Likewise, vitamin premix utilized in treatment and control diets was identical, and contained a minimum of $3,080,000 \mathrm{IU} / \mathrm{kg}$ of Vitamin A, 1,100,000 IU/kg of Vitamin $\mathrm{D}_{3}$, and 6,600 IU/kg of Vitamin E on a DM basis.

Shelled corn, whole oats, alfalfa cubes, beet pulp pellets, and SBH pellets were ground via a hammer mill through a $3.175 \mathrm{~mm}$ pore screen, in sequence with a singlescrew vertical mixer, and allowed to dry-mix for a minimum duration of ten minutes 
following the addition of vitamin premix, mineral premix, and salt at the mixer spout. After completion of dry-mixing, soybean oil, followed by SBM, were added at the mixer spout, and allowed to wet-mix for a minimum duration of twenty minutes. Diets were then augered to a sack-off bin where they were bagged. Bag one $(22.68 \mathrm{~kg})$ of each diet was discarded as a clean out bag for each dietary treatment. After bagging, diets were closed, stacked, and stored at ambient temperature in the feed mill for two days prior to pelleting. Single batches of $158.76 \mathrm{~kg}$ per respective treatment were manufactured. Likewise, a single batch of $385.55 \mathrm{~kg}$ of control diet was manufactured. Whole shelled corn $(90.72 \mathrm{~kg})$ was ground via hammer mill and allowed to mix for duration of 10 minutes following bagging of each treatment. Ground and mixed corn was then transported through the same auger system to the same sack-off bin, bagged, and discarded as a flushing procedure. Previously manufactured diets were then pelleted utilizing a 40 horsepower California pellet mill after re-mixing for a minimum duration of ten minutes. Basal control diet $(45.36 \mathrm{~kg})$ was mixed and pelleted between dietary treatments as an additional flushing procedure to ensure no dietary leaf meal contamination. Diets were then stored at ambient temperature in the feed mill until time of feeding. An identical procedure was carried out for the manufacture and handling of each diet.

\section{Experimental Diet Chemical Composition}

Proximate Analysis and Fiber Determination: Representative samples of growing lamb diets, pre- and post-pelleting, were collected in a similar manner as described for leaf meal chemical composition. Dry matter, OM, CP, SCP, NDF, ADF, 
ADL, CPNDF, and CPADF of pelleted and non-pelleted growing lamb diets (Table 2) were measured utilizing identical procedures to those described for the proximate analysis and fiber determination portion of leaf meal chemical composition.

Phenol Analysis: Representative samples of pelleted and non-pelleted growing lamb diets were collected in a similar manner as described for leaf meal chemical composition. Prussian blue assay and PPA of pelleted and non-pelleted growing lamb diets were conducted utilizing identical procedures to those described under the phenol analysis portion of leaf meal chemical composition.

\section{Experimental Diet Pellet Quality}

Pellet quality of pelleted experimental growing lamb diets was measured using procedures outlined by the ASAE (1997). In brief, after sifting through a No. 6 American Society for Testing and Materials (ASTM) screen, $500 \mathrm{~g}$ of sifted pellets were placed in a $0.3048 \mathrm{~m} \times 0.3048 \mathrm{~m}$ tumbler, and tumbled at $50 \mathrm{rpm}$ for duration of 10 minutes. After tumbling, samples were sifted through a No. 6 ASTM screen, and the remaining pellets were weighed. Pellet durability index (PDI) was calculated by dividing post tumble sifted pellet weight by weight of pellets prior to tumbling, followed by multiplication by one hundred. Modified pellet durability index (MPDI) was determined using a similar procedure and calculation, additionally utilizing the incorporation of five $13 \mathrm{~mm}$ hex nuts to pellets throughout the duration of tumbling in order to simulate stress to pellets associated with handling. 


\section{Growing Lamb Metabolism}

Lambs were fed ad libitum at 07:30 AM each day. At feeding, feed refusal from the previous day was collected, and weighed. Dry matter intake was measured on a daily basis and expressed as a percentage of BW.

Urine and feces were collected separately over a period of three days, immediately following feeding. Urine was collected continuously throughout the collection period into containers with 100 milliliters of a 2:1 ratio of $\mathrm{H}_{2} \mathrm{O}: 0.1 \mathrm{~N} \mathrm{HCl}$. Urine measurements occurred at 07:45 AM of each collection day. Urine was strained through cheese cloth before being mixed thoroughly. Total volume was measured immediately following mixture of urine. A single representative sample (a minimum of ten percent of the total volume of daily urinary output) was transferred to plastic centrifuge tubes $\left(50 \mathrm{~mL}\right.$; Fisherbrand), sealed, frozen, and stored at $0^{\circ} \mathrm{C}$ until further analysis. Remaining urine was removed from collection containers each day prior to replacement of $\mathrm{H}_{2} \mathrm{O}: 0.1 \mathrm{~N} \mathrm{HCl}$.

Feces were collected continuously throughout the collection period via open containers. Feces were mixed thoroughly in containers prior to being weighed. A single representative sample for each lamb (a minimum of twenty percent of the total daily fecal output) was transferred to plastic containers, sealed, frozen, and stored at $0^{\circ} \mathrm{C}$ until further analysis. Remaining feces were then removed from each bucket prior to cleaning and re-placement underneath the respective metabolism crate.

Blood samples were collected at $0,4,8,12,16,20$, and 24 hours post feeding via jugular veinipuncture with disposable needles (20 gauge, 1 inch Kendall monoject polypropylene hub hypodermic needles; Tyco Healthcare Group) and syringes (10 mL; 
Exelint International Co.) throughout the collection period. A minimum of $5 \mathrm{~mL}$ of blood was collected from each lamb at each time point, and immediately transferred to an individual blood collection tube (10 mL Kendall monoject; Tyco Healthcare Group) containing $0.10 \mathrm{~mL}$ of a $15 \% \operatorname{EDTA}\left(\mathrm{K}_{3}\right)$ solution before being placed on ice in a cooler. After completion of blood sample collection for a respective time point, samples were refrigerated at $4^{\circ} \mathrm{C}$ for two hours prior to centrifugation at $4000 \mathrm{x}$ g for duration of thirty minutes. Plasma was then transferred to $15 \times 45$ millimeter clear sepcap vials (National Scientific), sealed, and stored at $-20^{\circ} \mathrm{C}$ until further analysis.

Upon analysis, feces were placed in a $50^{\circ} \mathrm{C}$ forced air oven for 3 days. Dry samples were then weighed for calculation of fecal DM. Feces were then ground through a $2 \mathrm{~mm}$ pore screen using a Wiley mill. Fecal samples were pooled by addition of 25 percent of total daily fecal output, by mass, on a daily DM basis, for a respective lamb, for each of three days over a collection period. After mixing thoroughly, proximate analysis was conducted to determine total $\mathrm{DM}, \mathrm{OM}$, and $\mathrm{CP}$ of feed and feces, utilizing procedures outlined by the AOAC International (2000). Soluble crude protein of feed and feces was determined using procedures described by Licitra et al. (1996). Neutral detergent fiber, ADF, and ADL of feed and feces were determined using procedures described by ANKOM Technology (2006). Crude protein bound to neutral detergent fiber, as well as CPADF were determined by performing the Kjeldahl procedure on NDF and ADF fractions of feed and feces. Total DMD, as well as individual nutrient digestibility was determined for NDF, ADF, ADL, CP, SCP, and OM utilizing procedures that were previously outlined and cited. 
Plasma and acidified urine samples were allowed to thaw overnight and equilibrate to room temperature prior to analysis. Acidified urine samples were thoroughly mixed with a vortex prior to being pooled. Acidified urine samples were pooled by addition of 10 percent of total daily urinary output, by volume, of a respective lamb, for each day, over a three day collection period. Pooled acidified urine samples were diluted with $\mathrm{H}_{2} \mathrm{O}$ 50-fold to produce a 1:49 volumetric dilution of acidified urine: $\mathrm{H}_{2} \mathrm{O}$. Plasma and pooled acidified urine samples were thoroughly mixed with a vortex prior to analysis. Quantitative urea nitrogen was measured colorimetrically at 520 nanometers via Quanticrom Urea Assay Kit (DIUR-500; BioAssay Systems, Hayward, CA). Plates were read using a SPECTRAmax PLUS 384 Microplate Spectrophotometer (Molecular Devices Corporation, Sunnyvale, CA) equipped with SOFTmaxPRO Software version 4.6 for Windows (Molecular Devices Corporation, Sunnyvale, CA). Acidified urine samples were also analyzed for $\mathrm{CP}$ utilizing the Kjeldahl procedure (AOAC International, 2000).

\section{$\underline{\text { Statistical Analyses }}$}

Statistical analyses for all experiments other than the growing lamb metabolism study were performed utilizing the general linear modeling procedure of Statistical Analysis Software (SAS). Statistical analyses for the growing lamb metabolism study were performed utilizing the mixed effects procedure of SAS. 


\section{Results and Discussion}

\section{Leaf Meal Chemical Composition}

\section{$\underline{\text { Proximate Analysis and Fiber Determination }}$}

Proximate analysis and fiber determination (Table 3) of WOLM and TPLM

indicate that respective feedstuffs vary in nutrient composition when compared to one another. These meals resemble many fruit residue byproduct feeds in that they are low protein, moderately fibrous feeds that potentially contain moderate quantities of other carbohydrate components. Results of these preliminary analyses show potential for WOLM and TPLM utilization and or replacement for some fibrous feeds in ruminant livestock diets. However, concern does exist in that leaves of many deciduous tree species have been shown to contain substantial amounts of tannins that may impact their utilization (Kumar and Vaithiyanathan, 1990).

\section{Phenol Analysis}

Tannins, along with other phenolic compounds, have many biological characteristics. Some of these characteristics may be beneficial, while others may be detrimental to animal production. Main effects of leaf species were present for TPC (P $<$ $0.001)$ and PPC $(\mathrm{P}<0.001)$ of WOLM and TPLM. White oak leaf meal contained a 17.4 fold $(\mathrm{P}<0.001)$ greater amount of TPC when compared to that of TPLM. However, WOLM only exhibited a 3.7 fold $(\mathrm{P}<0.01)$ greater PPC when compared to that of TPLM. Respective values are reported in Table 4. 
Results indicate the presence of phenolic and/or tannin-like compounds, as well as the ability of compounds within WOLM to precipitate protein to a much greater extent than that of TPLM. These results are consistent with previous reports (Vitti et al., 2005; Mupangwa et al., 2000; Mangan, 1988; Kumar and Singh, 1984) that have indicated the presence of tannins in leaves of Quercus species.

In situ Ruminal Dry Matter Digestibility of White Oak and Tulip Poplar Leaf Meals In situ ruminal DMD differed $(\mathrm{P}<0.001)$ between WOLM and TPLM at all tested time points. Dry matter digestibility was greater $(\mathrm{P}<0.001)$ for TPLM when compared to WOLM at respective time points (Figure 1). Within treatment, main effects of time were present $(\mathrm{P}<0.05)$ for In situ ruminal DMD of WOLM. In situ ruminal DMD of WOLM did not differ $(\mathrm{P}>0.05)$ at $0,1,2$, and 4 hours of incubation in the rumen, potentially showing tannin induced bacterial inhibition. However, In situ ruminal DMD increased $(\mathrm{P}<0.01)$ at $8,12,24,48$, and 72 hours of incubation in the rumen.

Main effects of time were present $(\mathrm{P}<0.05)$ for In situ ruminal DMD of TPLM. Zero verses $1 \mathrm{hr}(\mathrm{P}=0.06)$, and 1 verses $2 \mathrm{hr}(\mathrm{P}=0.08)$ incubations tended to differ while all other time point comparisons demonstrated increasing $(\mathrm{P}<0.05)$ DMD.

Results indicate that following the onset of digestion, rate of In situ ruminal DMD appeared to increase through 24 hours of incubation in the rumen for both WOLM and TPLM. Conversely, rate of In situ ruminal DMD appeared to decline after 24 hours of incubation in the rumen for both WOLM and TPLM. 


\section{$\underline{\text { Feed Manufacture and Growing Lamb Metabolism }}$}

\section{$\underline{\text { Phenol Analysis of Experimental Growing Lamb Diets }}$}

Many previous reports have focused on utilization of tree leaves as ruminant feeds utilized during droughts or at times of last resort. Beyond the scope of white oak and tulip poplar leaf utilization as a "drought" or "time of need" feed, incorporation of these leaf meals as a component of a complete feed may have greater utility. Thus, chemical properties of meals of these leaves may have important effects on total diet nutrient availabilities and may be further altered with diet processing techniques such as pelleting.

There was an interaction of diet and processing method for TPC $(\mathrm{P}<0.001)$ of experimental growing lamb diets (Table 5). Diets that contained WOLM had the greatest $(\mathrm{P}<0.01)$ content of TPC regardless of processing method. However, processing had no effect $(\mathrm{P}>0.05)$ on diets that contained TPLM while it decreased $(\mathrm{P}<0.01)$ TPC in diets that contained WOLM as well as the BA diet. Total phenolic compounds of the nonpelleted HOLM diet was found to be the greatest $(1.95 \mathrm{CE} ; \mathrm{P}<0.01)$ and the pelleted BA diet contained the lowest $(0.37 \mathrm{CE} ; \mathrm{P}<0.01)$, while TPC of both differed $(\mathrm{P}<0.05)$ from all other diets. Though lower $(\mathrm{P}<0.01)$ than that of the non-pelleted HOLM diet, TPC of the non-pelleted LOLM (1.37 CE) and the pelleted HOLM (1.31 CE) diets were greater $(\mathrm{P}<0.05)$ than that of all other diets. Total phenolic compounds of the pelleted and non-pelleted HPLM and LPLM diets, and the non-pelleted BA diet did not differ (P $>0.05$ ) from that of one another. Replacement of SBH with TPLM did not affect the dietary level of phenolic compounds, regardless of replacement level. Conversely, replacement of SBH with WOLM resulted in an increased level of TPC in both pelleted and non-pelleted experimental growing lamb diets. 
These results indicate that TPC of diets that contained WOLM, as well as diets that contained no leaf inclusion may have been susceptible to destruction or conversion to compounds undetected by the PBA as a result of the pelleting process. Presence of TPC in diets that contained TPLM remained unaffected, indicating the potential for an ability to withstand destruction or inactivation by the pelleting process, and/or the presence of non-phenolic compounds that are recognized as phenolic compounds by the PBA.

Similar to the results of the PBA analysis, PPA analysis also revealed an interaction $(\mathrm{P}<0.01)$ between diet and processing method. Protein precipitating capability of the BA diet did not differ $(\mathrm{P}>0.05)$ due to processing. However, all other diets demonstrated a decrease $(\mathrm{P}<0.05)$ in PPC after pelleting. Non-pelleted HPLM had the greatest $(0.81 \mathrm{CE} ; \mathrm{P}<0.01)$ PPC while that of the pelleted LOLM and LPLM diets were similar $(0.33$ vs. $0.23 \mathrm{CE} ; \mathrm{P}>0.05)$ to each other, but lower $(\mathrm{P}<0.05)$ than all other diets. Within leaf meal containing diets, only those containing TPLM contained levels of PPC that increased with increasing leaf meal incorporation $(\mathrm{P}<0.05)$.

These results indicate potential resistance to destruction of, or conversion from phenolic compounds present in diets without SBH replacement, to non-phenolic compounds as a result of the pelleting process. Little is known about SBH-related phenolics and their sensitivity to the pelleting process. Protein precipitating compounds of SBH may have the ability to withstand destruction or inactivation by the pelleting process. A portion of PPC of diets containing WOLM or TPLM at both high and low inclusion rates may be destroyed or deactivated as a result of the pelleting process. 


\section{Experimental Diet Pellet Quality}

Main effects of leaf treatment were present for the PDI $(\mathrm{P}<0.001)$ and MPDI $(\mathrm{P}$ $<0.001$ ) of growing lamb diets (Table 6). Pellet durability index of the HPLM diet (86.55) was greater $(\mathrm{P}<0.01)$ than that of the LPLM, HOLM, BA, and LOLM diets. Similar $(\mathrm{P}>0.05)$ to that of each other, PDI of the LPLM and HOLM diets (83.10 vs. 82.10) was less $(\mathrm{P}<0.01)$ than that of the HPLM diet, while greater than that of the BA (80.45; $\mathrm{P}<0.05)$ and LOLM (76.80; $\mathrm{P}<0.01)$ diets. Pellet durability index of the LOLM diet was less $(\mathrm{P}<0.01)$ than that of all other diets. Likewise, MPDI of the HPLM diet was greater $(74.30 ; \mathrm{P}<0.01)$ than that of all other diets. Though lower $(\mathrm{P}<0.001)$ than that of the HPLM diet, MPDI of the HOLM diet was greater $(69.40 ; \mathrm{P}<0.01)$ than that of the LPLM, BA, and LOLM diets. Modified pellet durability index of the LPLM diet (65.35) did not differ $(\mathrm{P}>0.05)$ from that of the BA diet (64.55). Modified pellet durability index of the LOLM diet was less $(56.80 ; \mathrm{P}<0.001)$ than that of all other diets.

Pellet quality of diets that utilized TPLM to replace SBH at both high and low levels, as well as diets that utilized WOLM to replace SBH at a high level was greater than that of diets that replaced no SBH. Furthermore, diets that utilized leaf meal to replace SBH at a high level exhibited greater pellet quality when compared to diets that utilized leaf meal to replace $\mathrm{SBH}$ at a low level, as well as diets that utilized no replacement of SBH with leaf meal.

\section{Growing Lamb Metabolism}

All diets fed to growing lambs utilized in the nutrient metabolism investigation (Table 1) were pelleted. There were no treatment effects of $\operatorname{diet}(\mathrm{P}>0.05)$ on DMI 
expressed as a percentage of $\mathrm{BW}$, or $\mathrm{CPD}$ in growing lambs. However, effects of treatment were present $(\mathrm{P}<0.05)$ for $\mathrm{DMD}$, NDFD, ADFD, and OMD of growing lambs (Table 7).

Dry-matter, ADF and OM digestibility's did not differ $(\mathrm{P}>0.05)$ between leaf meal treatments. Furthermore, DM, ADF and OM digestibility's did not differ $(\mathrm{P}>0.05)$ between BA $(74.76,81.87$, and $57.09 \%)$ and $\operatorname{HPLM}(71.12,76.35$, and $51.63 \%)$ treatments, respectively. Dry matter, ADF, and OM digestibility's of lambs that received BA were greater $(\mathrm{P}<0.05)$ than in lambs that received LOLM, HOLM and LPLM diets. The digestibility of NDF in lambs that received the LPLM was less $(35.08 \% ; \mathrm{P}<0.05)$ than in lambs that received HPLM (44.02\%), but similar $(\mathrm{P}>0.05)$ to lambs that received LOLM and HOLM.

Results indicate that WOLM and TPLM effectively replaced SBH without affecting DMI expressed as a percentage of $\mathrm{BW}$, or CPD in growing lambs. However, results also indicate decreased DMD, NDFD, and ADFD as a result of replacement of SBH with WOLM, regardless of replacement level, and TPLM replacing 50 percent of DM from SBH, which may potentially be explained as a result of respective nutrient and phenolic or tannin-like compound interactions. Replacement of 100 percent of DM from SBH with TPLM did not affect DMD, NDFD, and ADFD. Likewise, replacement of 100 percent of DM from SBH with WOLM or TPLM did not affect OMD.

No treatment by time interaction was observed $(\mathrm{P}>0.05)$ for PUN of growing lambs. However, a main effect of treatment $(\mathrm{P}<0.001)$ on PUN of growing lambs was present (Table 8). Plasma urea nitrogen of lambs that received the LPLM, HPLM, and BA diets was similar $(\mathrm{P}>0.05)$ to one another. Lambs that received the HOLM diet 
exhibited lower $(\mathrm{P}<0.05)$ PUN when compared to lambs that received the LPLM and HPLM diets. However, PUN of lambs that received the HOLM diet was similar (P > 0.05 ) to that of lambs that received the BA diet. Lambs that received the LOLM diet exhibited the lowest $(\mathrm{P}<0.001)$ PUN $(446.48 \mathrm{mg} / \mathrm{dL})$ when compared to other treatments.

Results indicate that PUN of growing lambs remained unaffected as a result of replacement of SBH with TPLM, regardless of replacement rate. Likewise, PUN of growing lambs remained unaffected as a result of replacement of SBH with a high level of WOLM. However, PUN of lambs that received diets that contained WOLM was lower when compared to that of lambs that received diets that contained TPLM, regardless of SBH replacement level. Likewise, PUN of lambs that received diets that contained a low level of replacement of SBH with WOLM was lower than that of lambs that received all other treatments. This may be the result of a slightly reduced CP content of diets that contained a low level of WOLM.

An expected trend for a main effect of time $(P=0.06$; data not shown $)$ on PUN of growing lambs was present, and can be explained as a normal physiological response to feeding. Mean PUN of lambs decreased after feeding, and continued to decrease until the time of next feeding, at 24 hours. No effect of treatment $(P>0.05)$ on UUN and UCP was detected, indicating no differences in nitrogen metabolism as a result of replacement of SBH with WOLM or TPLM. 


\section{Conclusions}

White oak leaf meal and TPLM vary in nutrient composition when compared to one another. These meals resemble many fibrous residue byproduct feeds that are commonly utilized as feedstuffs throughout much of animal production, as they appear to be low protein, moderate fiber feeds with moderate quantities of other carbohydrate components. Results of the studies reported within indicate potential for utilization of WOLM and TPLM as alternatives to other fibrous feedstuffs in ruminant diets. These results also indicate that, as with many commonly utilized conventional feedstuffs, WOLM and TPLM contain anti-nutritive factors, such as phenolic or other tannin-like compounds, which may delay and/or alter digestion in the rumen without affecting intake when incorporation was limited to twenty percent of the total dietary dry matter. Compounds within WOLM appear to have the ability to precipitate protein to a much greater extent than those of TPLM. However, a portion of PPC of diets containing WOLM or TPLM may be destroyed or deactivated as a result of the pelleting process. As a benefit of this compound-protein interaction, incorporation of WOLM and TPLM in complete feeds may be an economical method of improving pellet quality, as pellet quality of experimental growing lamb diets increased with increasing replacement of SBH with leaf meal. In this study, no toxic effects of feeding WOLM and TPLM were observed in growing lambs.

Further research is warranted to more fully understand the potential utilization of WOLM and TPLM as alternative feeds for ruminants. Analysis of different WOLM and TPLM sources are necessary to more accurately define a more representative chemical 
composition of these leaf meals. In order to determine the optimum level of utilization, it is first necessary to more fully understand the microbiological effects of WOLM and TPLM in the rumen, which may help to explain effects of growing lamb nutrient digestibility. Likewise, it is necessary to determine if domestic ruminant livestock have the ability to adapt to phenolics and/or tannin-like compounds present in WOLM and TPLM, as well as to determine toxic levels, if any, of respective leaf meals, in order to establish maximum replacement limits. 


\section{References}

Aerts, R.J., Barry, T.N., and W.C. McNabb. 1999. Polyphenols and Agriculture: Beneficial Effects of Proanthocyanidins in Forages. Agriculture, Ecosystems \& Environment. 75:1-12.

AOAC International. 2000. Official Methods of Analysis of AOAC International. $17^{\text {th }}$ Edition. Gaithersburg, MD.

ANKOM Technology. 2006. ANKOM Procedures for NDF, ADF, and ADL. http://www.ankom.com/procedures.aspx.

ASAE. 2007. ASAE S269.4: Cubes, Pellets, and Crumbles-Definitions and Methods for Determining Density, Durability, and Moisture Content. Standards of the American Society of Agricultural and Biological Engineers.

Asquith, T.N., and L.G. Butler. 1986. Interactions of Condensed Tannins with Selected Proteins. Phytochemistry. 25:1591-1593.

Austin, P.J., Suchar, L.A., Robbins, C.T., and A.E. Hagerman. 1989. Tannin-Binding Proteins in Saliva of Deer and Their Absence in Saliva of Sheep and Cattle. Journal of Chemical Ecology. 15:1335-1347.

Baird, D.M. 1973. Influence of Pelleting Swine Diets on Metabolizable Energy, Growth and Carcass Characteristics. Journal of Animal Science. 36:516-521.

Barahona, R., Lascano, C.E., Cochran, R., Morrill, J., and E.C. Titgemeyer. 1997. Intake, Digestion, and Nitrogen Utilization by Sheep Fed Tropical Legumes with Contrasting Tannin Concentration and Astringency. Journal of Animal Science. 75:1633-1640.

Barry, T.N., and T.R. Manley. 1984. The Role of Condensed Tannins in the Nutritional Value of Lotus pedunculatus for Sheep: 2. Quantitative Digestion of Carbohydrates and Protein. British Journal of Nutrition. 51:493-504.

Barry, T.N., McNeill, D.M., and W.C. McNabb. 2001. Plant Secondary Compounds; Their Impact on Nutritive Value and Upon Animal Production. Proceedings of the IX International Grassland Conference. Sao Paolo, Brazil. 445-452.

Bate-Smith, E.C. 1973. Haemanalysis of Tannins: The Concept of Relative Astringency. Phytochemistry. 12:907-912. 
Behnke, K.C. 1994. Factors Affecting Pellet Quality. Maryland Nutrition Conference. Department of Poultry Science and Animal Science, College of Agriculture, University of Maryland, College Park.

Behnke, K.C. 2001. Factors Influencing Pellet Quality. In: FeedTech. 5:19-22.

Bell, D.D. 2003. Historical and Current Molting Practices in the U.S. Table Egg Industry. Poultry Science. 82:965-970.

Bernard, L., Chaise, J.P., Baumont, R., and C. Poncet. 2000. The Effect of Physical Form of Orchardgrass Hay on the Passage of Particulate Matter through the Rumen of Sheep. Journal of Animal Science. 78:1338-1354.

Biggs, P.E., Persia, M.E., Koelkebeck, K.W., and C.M. Parsons. 2004. Further Evaluation of Nonfeed Removal Methods for Molting Programs. Poultry Science. $83: 745-752$.

Blasi, D.A, and J. Drouillard. 2002. Composition and Feeding Value of Cottonseed Feed Products for Beef Cattle. Kansas State University Agricultural Experiment Station and Cooperative Extension Service.

Blosser, T.H., and A.O. Shaw. 1959. Effect of Pelleting on Rate of Concentrate Consumption by Dairy Cows. Journal of Dairy Science. 42:936.

Briggs, J.L., Maier, D.E., Watkins, B.A., and K.C. Behnke. 1999. Effect of Ingredients and Processing Parameters on Pellet Quality. Poultry Science. 78:1464-1471.

Broderick, G.A. 1978. In vitro Procedures for Estimating Rates of Ruminal Protein Degradation and Proportions of Protein Escaping the Rumen Undegraded. Journal of Nutrition. 108:181-190.

Brown, P.J., and W.B. Wright. 1964. An Investigation of the Interaction between Milk Proteins and Tea Polyphenols. Journal of Chromatography. 11:504-514.

Buchanan, N.P., Lilly, K.G.S., Gehring, C.K., and J.S. Moritz. 2008. The Effect of Diet Formulation and Manufacturing Technique on Pellet Processing Variables and Quality. Poultry Science. 87(Supplement 1):166. Abstract.

Butter, N.L. Dawson, J.M., Wakelin, D., and P.J. Buttery. 2000. Effect of Dietary Tannin and Protein Concentration on Nematode Infection (Trichostrongyus colubriformis) in Lambs. Journal of Agricultural Science. 134:89-99.

Cavalcanti, W.B., and K.C. Behnke. 2005a. Effect of Composition of Feed Model Systems on Pellet Quality: A Mixture Experimental Approach I. Cereal Chemistry. 82:455-461. 
Cavalcanti, W.B., and K.C. Behnke. 2005b. Effect of Composition of Feed Model Systems on Pellet Quality: A Mixture Experimental Approach II. Cereal Chemistry. 82:462-467.

Chavan, J.K., Kadam, S.S., Ghonsikar, C.P., and D.K. Salunkhe. 1979. Removal of Tannins and Improvement of In vitro Protein Digestibility of Sorghum Seeds by Soaking in Alkali. Journal of Food Science. 44:1319-1322.

Clarke, R.T.J., and C.S.W. Reid. 1974. Foamy Bloat of Cattle: A Review. Journal of Dairy Science. 57:753-785.

Cole, N.A., Johnson, R.R., and F.N. Owens. 1976. Influence of Roughage Level and Corn Processing Method on Site and Extent of Digestion by Beef Steers. Journal of Animal Science. 43:490-496.

Cutlip, S.E., Hott, J.M., Buchanan, N.P., Rack, A.L., Latshaw, J.D., and J.S. Moritz. 2008. The Effect of Steam Conditioning Practices on Pellet Quality and Growing Broiler Nutritional Value. Journal of Applied Poultry Research. 17:249-261.

Dalke, B.S., Sonon Jr., R.N., Young, M.A., Huck, G.L., Kreikemeier, K.K., and K.K. Bolsen. 1997. Wheat Middlings in High-Concentrate Diets: Feedlot Performance, Carcass Characteristics, Nutrient Digestibilities, Passage Rates, and Ruminal Metabolism in Finishing Steers. Journal of Animal Science. 75:25612566.

Davis, A.J., Lordelo, M.M., and N. Dale. 2002. Use of Cottonseed Meats in Molting Programs. Journal of Applied Poultry Research. 11:175-178.

Defoor, P.J., Galyean, M.L., Salyer, G.B., Nunnery, G.A., and C.H. Parsons. 2002. Effects of Roughage Source and Concentration on Intake and Performance by Finishing Heifers. Journal of Animal Science. 80:1395-1404.

Dhuyvetter, J., Hoppe, K., and V. Anderson. 1999. Wheat Middlings: A Useful Feed for Cattle. North Dakota State University Publication AS-1175. North Dakota State University, Fargo.

DiCostanzo, A., Meiske, J.C., and H. Chester-Jones. 1994. Minnesota Cattle Feeder Report B-415. University of Minnesota, St. Paul. Southern Experiment Station, Waseca.

Dinius, D.A., Goering, H.K., Oltjen, R.R., and H.R. Cross. 1978. Finishing Beef Steers on Forage Diets with Additives and Supplemental Lipid. Journal of Animal Science. 46:761-768.

Donalson, L.M., Kim, W.K., Woodward, C.L., Herrera, P., Kubena, L.F., Nisbet, D.J., and S.C. Ricke. 2005. Poultry Science. 84:362-369. 
Donnelly, E.D. 1954. Some Factors that Affect Palatability in Sericea Lespedeza, Lespedeza cuneata. Agronomy Journal. 46:96-97.

Erickson, D.O., Moore, B.L., Berg, P.T., and M. Swantek. 1989. Distillers Dried Grains Compared to Soybean Meal in Barley or Milo Diets for Finishing Lambs. Western Dakota Sheep Day. 30:6-11.

Esplin, A.L., Garrigus, U.S., Hatfield, E.E., and R.M. Forbes. 1957. Some Effects of Pelleting a Ground Mixed Ration on Feed Utilization by Fattening Lambs. Journal of Animal Science. 16:863-871.

Firkins, J.L., Berger, L.L., and G.C. Fahey Jr. 1985. Evaluation of Wet and Dry Distillers Grains and Wet and Dry Corn Gluten Feeds for Ruminants. Journal of Animal Science. 60:847-860.

Folin, O., and W. Denis. 1915. A Colorimetric Method for the Determination of Phenols (and Phenol Derivatives) in Urine. The Journal of Biological Chemistry. 22:305308.

Fontenot, J.P., and H.A. Hopkins. 1965. Effect of Physical Form on Different Parts of Lamb Fattening Rations on Feedlot Performance and Digestibility. Journal of Animal Science. 24:62-68.

Frutos, P., Hervás, G., Giráldez, F.J., and A.R. Mantecón. 2004. Review: Tannins and Ruminant Nutrition. Spanish Journal of Agricultural Research. 2:191-202.

Galyean, M.L., Wagner, D.G., and R.R. Johnson. 1976. Site and Extent of Starch Digestion in Steers Fed Processed Corn Rations. Journal of Animal Science. 43:1088-1094.

Galyean, M.L., Wagner, D.G., and F.N. Owens. 1979. Corn Particle Size and Site and Extent of Digestion by Steers. Journal of Animal Science. 49:204-210.

Galyean, M.L., Wagner, D.G., and F.N. Owens. 1981. Dry Matter and Starch Disappearance of Corn and Sorghum as Influenced by Particle Size and Processing. Journal of Dairy Science. 64:1804-1812.

Garg, S.K., Makkar, H.P., Nagal, K.B., Sharma, S.K., Wadhwa, D.R., and B. Singh. 1992. Oak (Quercus incana) Leaf Poisoning in Cattle. Veterinary and Human Toxicology. 34:161-164.

Gehring, C.K. 2009. Improvement of the Physical and Nutritional Quality of Pellets. M.S. Thesis. West Virginia University, Morgantown. 
Gehring, C.K., Jaczynski, J., and J.S. Moritz. 2009. Improvement of Pellet Quality with Proteins Recovered from Whole Fish Using Isoelectric Solubilization/Precipitation. Journal of Applied Poultry Research. 18:418-431.

Goldstein, J.L., and T. Swain. 1963. Changes in Tannins in Ripening Fruits. Phytochemistry. 2:371-383.

Gould, D.H. 1998. Polioencephalomalacia. Journal of Animal Science. 76:309-314.

Greer, D., and F. Fairchild. 1999. Cold Mash Moisture Control Boosts Pellet Quality. Feed Management. 50:20-21.

Guthrie, M.J., Galyean, M.L., Malcolm-Callis, K.J., and G.C. Duff. 1996. Roughage Source and Level in Beef Cattle Finishing Diets. Journal of Animal Science. 12:192-198.

Hagerman, A.E., and L.G. Butler. 1978. Protein Precipitation Method for the Quantitative Determination of Tannins. Journal of Agricultural and Food Chemistry. 26:809-812.

Hagerman, A.E., and L.G. Butler. 1980. Condensed Tannin Purification and Characterization of Tannin-Associated Proteins. The Journal of Agricultural and Food Chemistry. 28:947-952.

Hagerman, A.E., and L.G. Butler. 1981. The Specificity of Proanthocyanidin-Protein Interactions. The Journal of Biological Chemistry. 256:4494-4497.

Hagerman, A.E., and L.G. Butler. 1989. Choosing Appropriate Methods and Standards for Assaying Tannin. Journal of Chemical Ecology. 15:1795-1810.

Hale, W.H., Cuitun, L., Saba, W.J., Taylor, B., and B. Theurer. 1966. Effect of Steam Processing and Flaking Milo and Barley on Performance and Digestion by Steers. Journal of Animal Science. 25:392-396.

Hanke, H.E., Rust, J.W., Meade, R.J., and L.E. Hanson. 1972. Influence of Source of Soybean Protein, and of Pelleting, on Rate of Gain and Gain/Feed of Growing Swine. Journal of Animal Science. 35:958-962.

Harris, H.B., and R.E. Burns. 1970. Influence of Tannin Content on Preharvest Seed Germination in Sorghum. Agronomy Journal. 62:835-836.

Haslam, E. 1974. Polyphenol-Protein Interactions: Short Communication. Biochemistry Journal. 139:285-288.

Haslam, E. 1979. Vegetable Tannins. In Recent Advances in Phytochemistry. 12:475521. 
Hatfield, P.G., Hopkins, J.A., Pritchard, G.T., and C.W. Hunt. 1997. The Effects of Amount of Whole Barley, Barley Bulk Density, and Form of Roughage on Feedlot Lamb Performance, Carcass Characteristics, and Digesta Kinetics. Journal of Animal Science. 75:3353-3366.

Hejazi, S., Fluharty, F.L., Perley, J.E., Loerch, S.C., and G.D. Lowe. 1999. Effects of Corn Processing and Dietary Fiber Source on Feedlot Performance, Visceral Organ Weight, Diet Digestibility, and Nitrogen Metabolism in Lambs. Journal of Animal Science. 77:507-515.

Held, J. 2006. Feeding Soy Hulls and Dried Distillers Grain with Solubles to Sheep. Extension Extra 2052. South Dakota State University Cooperative Extension Service. South Dakota State University, Brookings.

Hersom, M.J. 2006. By-Product Feed Utilization for Forage Diets. Florida Beef Cattle Short Course Publication. University of Florida, Gainesville.

Hott, J.M. 2007. The Effect of Moisture Addition with a Mold Inhibitor on Feed Manufacture, Pellet Quality, and Broiler Performance. M.S. Thesis. West Virginia University, Morgantown.

Hull, S.J., Waldroup, P.W., and E.L. Stephenson. 1968. Utilization of Unextracted Soybeans by Broiler Chicks. II. Influence of Pelleting and Regrinding on Diets with Infra-red Cooked and Extruded Soybeans. Poultry Science. 47:1115-1120.

Huls, T.J., Bartosh, J.A., Daniel, A., Zelinsky, R.D., Held, J., and A.E. Wertz-Lutz. 2006. Efficacy of Dried Distiller's Grains with Solubles as a Replacement for Soybean Meal and a Portion of the Corn in a Finishing Lamb Diet. Sheep and Goat Research Journal. 21:30-34.

Hsu, J.T., Faulkner, D.B., Garleb, K.A., Barclay, R.A., Fahey Jr., G.C., and L.L. Berger. 1987. Evaluation of Corn Fiber, Cottonseed Hulls, Oat Hulls and Soybean Hulls as Roughage Sources for Ruminants. Journal of Animal Science. 65:244-255.

Hussar, N., and A.R. Robblee. 1962. Effect of Pelleting on the Utilization of Feed by the Growing Chicken. Poultry Science. 41:1489-1493.

Jansman, A.J.M. 1993. Tannins in Feedstuffs for Simple-Stomached Animals. Nutrition Research Reviews. 6:209-236.

Jensen, A.H., and D.E. Becker. 1965. Effect of Pelleting Diets and Dietary Components on the Performance of Young Pigs. Journal of Animal Science. 24:392-397.

Jones, W.T., and J.W. Lyttleton. 1972. Bloat in Cattle (XXXVI). Further Studies on the Foaming Properties of Soluble Leaf Proteins. New Zealand Journal of Agricultural Research. 15:267-278. 
Jones, W.T., and J.L. Mangan. 1977. Complexes of the Condensed Tannins of the Sainfoin (Onobrychis viciifolia Scop.) with Fraction 1 Leaf Protein and with Submaxillary Mucoprotein, and Their Reversal by Polyethylene Glycol and pH. Journal of the Science of Food and Agriculture. 28:126-136.

Jones, F.T., Anderson, K.T., and P.R. Ferket. 1995. Effect of Extrusion on Feed Characteristics and Broiler Chicken Performance. Journal of Applied Poultry Research. 4:300-309.

Kellems, R.O., and D.C. Church. 2002. Livestock Feeds and Feeding. Fifth Edition. Pearson Education, Inc. Upper Saddle River, NJ.

Keshavarz, K., and F.W. Quimby. 2002. An Investigation of Different Molting Techniques with an Emphasis on Animal Welfare. Journal of Applied Poultry Research. 11:54-67.

Kimambo, A.E., MacRae, J.C., Walker, A., Watt, C.F., and R.L. Coop. 1988. Effect of Prolonged Subclinical Infection with Trichostrongylus colubriformis on the Performance and Nitrogen Metabolism of Growing Lambs. Veterinary Parasitology. 28:191-203.

Klopfenstein, T.J., Erickson, G.E., and V.R. Bremer. 2008. BOARD-INVITED REVIEW: Use of Distillers By-Products in the Beef Cattle Feeding Industry. Journal of Animal Science. 86:1223-1231.

Koelkebeck, K.W., Parsons, C.M., Biggs, P., and P. Utterback. 2006. Nonwithdrawal Molting Programs. Journal of Applied Poultry Research. 15:483-491.

Kumar, R., and M. Singh. 1984. Tannins: Their Adverse Role in Ruminant Nutrition. Journal of Agricultural and Food Chemistry. 32:447-453.

Kumar, R., and S. Vaithiyanathan. 1990. Occurrence, Nutritional Significance and Effect on Animal Productivity of Tannins in Tree Leaves. Animal Feed Science and Technology. 30:21-38.

Lalman, D. 1996. Alternative Feeds for Beef Cows and Stockers. University Extension Publication. University of Missouri - Columbia, Columbia.

Landers, K.L., Woodward, C.L., Kubena, L.F., Nisbet, D.J., and S.C. Ricke. 2005 a. Alfalfa as a Single Dietary Source for Molt Induction in Laying Hens. Bioresource Technology. 96:565-570.

Landers, K.L., Howard, Z.R., Woodward, C.L., Birkhold, S.G., and S.C. Ricke. 2005 b. Potential of Alfalfa as an Alternative Molt Induction Diet for Laying Hens: Egg Quality and Consumer Acceptability. Bioresource Technology. 96:907-911. 
Lardy, G. 1999. Feeding Barley to Sheep. University Extension Publication. North Dakota State University, Department of Animal and Range Sciences, Fargo.

Lardy, G., and V. Anderson. 2009. Alternative Feeds for Ruminants. North Dakota State University Publication AS-1182. North Dakota State University, Fargo.

Lassiter, C.A., Denton, T.W., Brown, L.D., and J.W. Rust. 1955. The Nutritional Merits of Pelleting Calf Starters. Journal of Dairy Science. 38:1242-1245.

Leathwick, D.M., Pomroy, W.E., and A.C.G. Heath. 2001. Anthelmintic Resistance in New Zealand. New Zealand Veterinary Journal. 49:227-235.

Licitra, G., Hernandez, T.M., and P.J. Van Soest. 1996. Standardization of Procedures for Nitrogen Fractionation of Ruminant Feeds. Journal of Animal Feed Science and Technology. 57:347-358.

Lilly, K.G.S., Gehring, C.K., Beaman, K.R., and J.S. Moritz. 2009. Examining the Relationship Between Pellet Quality, Broiler Performance, and Bird Sex. Poultry Science. 88(Supplement I):143(Abstract).

Long, T.A., Nelson, A.B., and R. MacVicar. 1955. Effect of Grinding and Pelleting upon Digestibility of a Ration by Lambs. Journal of Animal Science. 14:947950.

Loomis, W.D. 1974. Overcoming Problems of Phenolics and Quinones in the Isolation of Plant Enzymes and Organelles. Methods in Enzymology. 31(Pt A):528-544.

Loy, D.D., and W. Miller. 2008. Ethanol Coproducts for Cattle. Iowa Beef Center - 18 . Iowa State University Extension. Iowa State University, Ames.

Ludden, P.A., Cecava, M.J., and K.S. Hendrix. 1995. The Value of Soybean Hulls as a Replacement for Corn in Beef Cattle Diets Formulated With or Without Added Fat. Journal of Animal Science. 73:2706-2711.

Lyford Jr., S.J., Smart, W.W.G., and T.A. Bell. 1967. Inhibition of Rumen Cellulose Digestion by Extracts of Sericea Lespedeza. Journal of Animal Science. 26:632637.

Makkar, H.P.S., Singh, B., and R.K. Dawra. 1988. Effect of Tannin-Rich Leaves of Oak (Quercus incana) on Various Microbial Enzyme Activities of the Bovine Rumen. British Journal of Nutrition. 60:287-296.

Mangan, J.L. 1972. Quantitative Studies on Nitrogen Metabolism in the Bovine Rumen. The Rate of Proteolysis of Casein and Ovalbumin and the Release and Metabolism of the Amino Acids. British Journal of Nutrition. 27:261-283. 
Mangan, J.L. 1988. Nutritional Effects of Tannins in Animal Feeds. Nutrition Research Reviews. 1:209-231.

Makkar, H.P.S. 1989. Protein Precipitation Methods for Quantitation of Tannins: A Review. Journal of Agricultural and Food Chemistry. 37:1197-1202.

Mantz, G.K., Villalba, J.J., and F.D. Provenza. 2009. Supplemental Polyethylene Glycol Affects Intake of and Preference for Sericea Lespedeza by Cattle. Journal of Animal Science. 87:761-769.

Martin, J.S., and M.M. Martin. 1982. Tannin Assays in Ecological Studies: Lack of Correlation Between Phenolics, Proanthocyanidins and Protein-Precipitating Constituents in Mature Foliage of Six Oak Species. Oecologia. 54:205-211.

Martin, J.S., and M.M. Martin. 1983. Tannin Assays in Ecological Studies. Precipitation of ribulose-1,5-biphosphate carboxylase/oxygenase by Tannic Acid, Quebracho, and Oak Foliage Extracts. Journal of Chemical Ecology. 9:285-294.

Mathison, G.W. 1996. Effects of Processing on the Utilization of Grain by Cattle. Animal Feed Science and Technology. 58:113-125.

McArthur, C., Sanson, G.D., and A.M. Beal. 1995. Salivary Proline-Rich Proteins in Mammals: Roles in Oral Homeostasis and Counteracting Dietary Tannin. Journal of Chemical Ecology. 21:663-691.

McLeod, M.N. 1974. Plant Tannins- Their Role in Forage Quality. Nutrition Abstracts and Reviews. 44:803-815.

McNabb, W.C., Waghorn, G.C., Barry, T.N., and I.D. Shelton. 1993. The Effect of Condensed Tannins in Lotus pedunculatus on the Digestion and Metabolism of Methionine, Cysteine and Inorganic Sulphur in Sheep. British Journal of Nutrition. 70:647-661.

McNabb, W.C., Waghorn, G.C., Peters, J.S., and T.N. Barry. 1996. The Effect of Condensed Tannins in Lotus pedunculatus on the Solubilisation and Degradation of ribulose-1,5-biphosphate carboxylase (EC 4.1.1.39; Rubisco) Protein in the Rumen and the Sites of Rubisco Digestion. British Journal of Nutrition. 76:535549.

McSweeney, C.S., Palmer, B., McNeill, D.M., and D.O. Krause. 2001. Microbial Interactions with Tannins: Nutritional Consequences for Ruminants. Animal Feed Science and Technology. 91:83-93.

Meyer, J.H., Gaskill, R.L., Stoewsand, G.S., and W.C. Weir. 1959. Influence of Pelleting on the Utilization of Alfalfa. Journal of Animal Science. 18:336-346. 
Min, B.R., McNabb, W.C., Barry, T.N., Demp, P.D., Waghorn, G.C., and M.F. McDonald. 1999. The Effect of Condensed Tannins in Lotus corniculatus upon Reproductive Efficiency and Wool Production in Sheep During Late Summer and Autumn. Journal of Agricultural Science. 132:323-334.

Min, B.R., Attwood, G.T., Reilly, K., Sun, W., Peters, J.S., Barry, T.N., and W.C. McNabb. 2002. Lotus corniculatus Condensed Tannins Decrease In vivo Populations of Proteolytic Bacteria and Affect Nitrogen Metabolism in the Rumen of Sheep. Canadian Journal of Microbiology. 48:911-921.

Min, B.R., Barry, T.N., Attwood, G.T., and W.C. McNabb. 2003. The Effect of Condensed Tannins on the Nutrition of Ruminants Fed Fresh Temperate Forages: A Review. Animal Feed Science and Technology. 106:3-19.

Min, B.R., and S.P. Hart. 2003. Tannins for Suppression of Internal Parasites. Journal of Animal Science. 81(E. Supp. 2):E102-E109.

Min, B.R., Pinchak, W.E., Fulford, J.D., and R. Puchala. 2005. Wheat Pasture Bloat Dynamics, In vitro Ruminal Gas Production, and Potential Bloat Mitigation with Condensed Tannins. Journal of Animal Science. 83:1322-1331.

Min, B.R., Pinchak, W.E., Anderson, R.C., Fulford, J.D., and R. Puchala. 2006. Effects of Condensed Tannins Supplementation Level on Weight Gain and In vitro and In vivo Bloat Precursors in Steers Grazing Winter Wheat. Journal of Animal Science. 84:2546-2554.

Minnestoa Corn Growers Association. 2001. Corn Milling, Processing and Generation of Co-products. Minnesota Nutrition Conference Technical Symposium.

Molan, A.L., Attwood, G.T., Min, B.R., and W.C. McNabb. 2001. The Effect of Condensed Tannins from Lotus pedunculatus and Lotus corniculatus on the Growth of Proteolytic Rumen Bacteria In vitro and Their Possible Mode of Action. Canadian Journal of Microbiology. 47:626-633.

Moran, E.T. 1989. Effect of Pellet Qaulity on the Performance of Meat Birds. In: Recent Advances in Animal Nutrition. Butterworths, London. 87-108.

Moritz, J.S., Wilson, K.J., Cramer, K.R., Beyer, R.S., McKinney, L.J., Cavalcanti, W.B., and X. Mo. 2002. Effect of Formulation Density, Moisture, and Surfactant on Feed Manufacturing, Pellet Quality, and Broiler Performance. Journal of Applied Poultry Research. 11:155-163.

Moritz, J.S., Cramer, K.R., Wilson, K.J., and R.S. Beyer. 2003. Feed Manufacture and Feeding of Rations with Graded Levels of Added Moisture Formulated at Different Energy Densities. Journal of Applied Poultry Research. 12:371-381. 
Muirhead, S. 1999. Precision in Mash Moisture Management Improves Pellets. Feedstuffs. 71:16.

Mupangwa, J.F., Acamovic, T., Topps, J.H., Ngongoni, N.T., and H. Hamudikuwanda. 2000. Content of Soluble and Bound Condensed Tannins of Three Tropical Herbaceous Forage Legumes. Animal Feed Science and Technology. 83:139144.

Niezen, J.H., Robertson, H.A., Waghorn, G.C., and W.A.G. Charleston. 1998. Production, Faecal Egg Counts, and Worm Burdens of Ewe Lambs which Grazed Six Contrasting Forages. Veterinary Parasitology. 80:15-27.

Nishimuta, J.F., Ely, D.G., and J.A. Boling. 1973. Nitrogen Metabolism in Lambs Fed Soybean Meal Treated with Heat, Formalin and Tannic Acid. Journal of Nutrition. 103:49-53.

National Research Council. 1996. Nutrient Requirements of Beef Cattle. Seventh Revised Edition. National Academy Press. Washington, D.C.

National Research Council. 2007. Nutrient Requirements of Small Ruminants: Sheep, Goats, Cervids, and New World Camelids. The National Academies Press. Washington, D.C.

Nugent, J.H.A., and J.L. Mangan. 1981. Characteristics of the Rumen Proteolysis of Fraction 1 (18S) Leaf Protein From Lucerne (Medicago sativa L.). British Journal of Nutrition. 46:39-59.

O’Donovan, L., and J.D. Brooker. 2001. Effect of Hydrolysable and Condensed Tannins on Growth, Morphology, and Metabolism of Streptococcus gallolyticus (S. caprinus) and Streptococcus bovis. Microbiology. 147:1025-1033.

Owens, F.N., Secrist, D.S., Hill, J.W., and D.R. Gill. 1997. The Effect of Grain Source and Grain Processing on Performance of Feedlot Cattle: A Review. Journal of Animal Science. 75:868-879.

Parker, R.J., and B. Palmer. 1991. Lack of Anthelmintic Effect of Calliandra calothyrsus in Sheep. Australian Veterinary Journal. 68:309.

Parsons, C.H., Vasconcelos, J.T., Swingle, R.S., Defoor, P.J., Nunnery, G.A., Salyer, G.B., and M.L. Galyean. 2007. Effects of Wet Corn Gluten Feed and Roughage Levels on Performance, Carcass Characteristics, and Feeding Behavior of Feedlot Cattle. Journal of Animal Science. 85:3079-3089.

Perez-Maldonado, R.A., Norton, B.W., and G.L. Kerven. 1995. Factors Affecting In Vitro Formation of Tannin-Protein Complexes. Journal of the Science of Food and Agriculture. 69:291-298. 
Plumlee, K.H., Johnson, B., and F.D. Galey. 1998. Comparison of Disease in Calves Dosed Orally with Oak or Commercial Tannic Acid. Journal of Veterinary Diagnostic Investigation. 10:263-267.

Pomroy, W.E. 2006. Anthelmintic Resistance in New Zealand: A Perspective on Recent Findings and Options for Future. New Zealand Veterinary Journal. 54:265-270.

Price, M.L., and L.G. Butler. 1977. Rapid Visual Estimation and Spectrophotometric Determination of Tannin Content of Sorghum Grain. Journal of Agricultural and Food Chemistry. 25:1268-1273.

Price, M.L., Van Scoyoc, S., and L.G. Butler. 1978. A Critical Evaluation of the Vanillin Reaction as an Assay for Tannin in Sorghum Grain. Journal of Agricultural and Food Chemistry. 26:1214-1218.

Price, M.L., Butler, L.G., Featherstone, W.R., and J.C. Rogler. 1978. Detoxification of High Tannin Sorghum Grain. Nutrition Reports International. 17:229-238.

Price, M.P., Hagerman, A.E., and L.G. Butler. 1980. Tannin in Sorghum Grain: Effect of Cooking on Chemical Assays and on Anti-nutritional Properties in Rats. Nutrition Reports International. 21:761-767.

Prichard, R. 1994. Anthelmintic Resistance. Veterinary Parasitology. 54:259-268.

Proudfoot, F.G., and H.W. Hulan. 1982. Feed Texture Effects on the Performance of Turkey Broilers. Poultry Science. 61:327-330.

Ramirez, R.G., Kiesling, H.E., Galyean, M.L., Lofgreen, G.P., and J.K. Elliott. 1985. Influence of Steam-Flaked, Steamed-Whole, or Whole Shelled Corn on Performance and Digestion in Beef Steers. Journal of Animal Science. 61:1-8.

Reed, J.D. 1995. Nutritional Toxicology of Tannins and Related Polyphenols in Forage Legumes. Journal of Animal Science. 73:1516-1528.

Reichert, R.D., Fleming, S.E., and D.J. Schwab. 1980. Tannin Deactivation and Nutritional Improvement of Sorghum by Anaerobic Storage of $\mathrm{H}_{2} \mathrm{O}-, \mathrm{HCl}-$, or $\mathrm{NaOH}-$ Treated Grain. Journal of Agricultural and Food Chemistry. 28:824-829.

Robbins, C.T., Mole, S., Hagerman, A.E., and T.A. Hanley. 1987. Role of Tannins in Defending Plants Against Ruminants: Reduction in Dry Matter Digestion. Ecology. 68:1606-1615.

Robinson, R. 1976. Basic Processing Operations: Pelleting - Introduction and General Definitions. Feed Manufacturing and Technology: American Feed Manufacturers Association, Inc. 103-110. 
Ruszler, P.L. 1998. Health and Husbandry Considerations of Induced Molting. Poultry Science. 77:1789-1793.

Salmon, R.E. 1985. Effects of Pelleting, Added Sodium Bentonite and Fat in a WheatBased Diet on Performance and Carcass Characteristics of Small White Turkeys. Animal Feed Science and Technology. 12:223-232.

Salunkhe, D.K., Chavan, J.K., and S.S. Kadam. 1990. VIII Tannins in Forages. Dietary Tannins: Consequences and Remedies. CRC Press. Boca Raton, FL. 67-76.

Scalbert, A. 1991. Review Article Number 63: Antimicrobial Properties of Tannins. Phytochemistry. 30:3875-3883.

Schauer, C.S., Anderson, L.P., Stecher, D.M., Pearson, D., and D. Drolc. 2005. Influence of Dried Distillers Grains on Feedlot Performance and Carcass Characteristics of Finishing Lambs. Western Dakota Sheep \& Beef Day. 46:3133.

Schauer, C.S., Stamm, M.M., Maddock, T.D., and P.B. Berg. 2008. Feeding of DDGS in Lamb Rations: Feeding Dried Distillers Grains with Solubles as 60 Percent of Lamb Finishing Rations Results in Acceptable Performance and Carcass Quality. Sheep \& Goat Research Journal. 23:15-19.

Schofield, P., Mbugua, D.M., and A.N. Pell. 2001. Analysis of Condensed Tannins: A Review. Animal Feed Science and Technology. 91:21-40.

Seo, K., Holt, P.S., and R.K. Gast. 2001. Comparison of Salmonella Enteritidis Infection in Hens Molted via Long-Term Feed Withdrawal versus Full-Fed Wheat Middling. Journal of Food Protection. 64:1917-1921.

Skoch, E.R., Behnke, K.C., Deyoe, C.W., and S.F. Binder. 1981. The Effect of SteamConditioning Rate on the Pelleting Process. Animal Feed Science and Technology. 6:83-90.

Skoch, E.R., Binder, S.F., and C.W. Deyoe. 1983a. Effects of Pelleting Conditions on Performance of Pigs Fed a Corn-Soybean Meal Diet. Journal of Animal Science. 57:922-928.

Skoch, E.R., Binder, S.F., and C.W. Deyoe. 1983b. Effects of Steam Pelleting Conditions and Extrusion Cooking on a Swine Diet Containing Wheat Middlings. Journal of Animal Science. 57:929-935.

Smart, W.W.G. Jr., Bell, T.A., and N.W. Stanley. 1961. Inhibition of Rumen Cellulase by an Extract from Sericea Forage. Journal of Dairy Science. 44:1945-1946.

Speetjens, J. 2002. Steam Flaked Grain. World Grain: Feed Operations. October:26-28. 
Spier, S.J., Smith, B.P., Seawright, A.A., Norman, B.B., Ostrowski, S.R., and M.N. Oliver. 1987. Oak Toxicosis in Cattle in Northern California: Clinical and Pathological Findings. Journal of the American Veterinary Medical Association. 191:958-964.

Stanton, T.L., and S.B. LeValley. 2006. Lamb Feedlot Nutrition. University Extension Publication no. 1.613. Colorado State University, Fort Collins.

Stock, R.A., Lewis, J.M., Klopfenstein, T.J., and C.T. Milton. 2000. Review of New Information on the Use of Wet and Dry Milling Feed By-Products in Feedlot Diets. Journal of Animal Science. 77:v-12.

Streeter, M.N., Wagner, D.G., Hibberd, C.A., and F.M. Owens. 1990. The Effect of Sorghum Grain Variety on Site and Extend of Digestion in Beef Heifers. Journal of Animal Science. 68:1121-1132.

Swain, T. 1979. Tannins and Lignins. Herbivores, Their Interaction with Secondary Plant Metabolites. New York: Academic Press. 657-682.

Theurer, C.B. 1986. Grain Processing Effects on Starch Utilization by Ruminants. Journal of Animal Science. 63:1649-1662.

Thomas, M., Van Vliet, T., and A.F.B. Van der Poel. 1998. Physical Quality of Pelleted Animal Feed. 1. Contribution of Feedstuff Components. Animal Feed Science and Technology. 70:59-78.

Thomson, D.J. 1972. Physical Form of the Diet in Relation to Rumen Fermentation. Proceedings of the Nutrition Society. 31:127-134.

Turgeon, O.A. Jr., Brink, D.R., and R.A. Britton. 1983. Corn Particle Size Mixtures, Roughage Level, and Starch Utilization in Finishing Steer Diets. Journal of Animal Science. 57:739-749.

Umberger, S.H. 2009. Whole-Grain Diets for Finishing Lambs. Virginia Cooperative Extension Publication 410-024. Virginia Polytechnic Institute and State University, Blacksburg.

USDA Economic Research Service. 2007. State Fact Sheet: West Virginia. http://www.ers.usda.gov/statefacts/WV.htm.

USDA Forest Service. 2006. Forest Inventory and Analysis National Program. http://fia.fs.fed.us/tools-data/default.asp.

Utley, P.R., Hellwig, R.E., Butler, J.L., and W.C. McCormick. 1973. Comparison of Unground, Ground, and Pelleted Peanut Hulls as Roughage Sources in Steer Finishing Diets. Journal of Animal Science. 37:608-611. 
Vasconcelos, J.T., and M.L. Galyean. 2007. Nutritional Recommendations of Feedlot Consulting Nutritionists: The 2007 Texas Tech University Survey. Journal of Animal Science. 85:2772-2781.

Vitti, D.M.S.S., Abdalla, A.L., Bueno, I.C.S., Silva Filho, J.C., Costa, C., Bueno, M.S., Nozella, E.F., Longo, C., Vieira, E.Q., Cabral Filho, S.L.S., Godoy, P.B., and I. Mueller-Harvey. 2005. Do all Tannins have Similar Nutritional Effects? A Comparison of Three Brazilian Fodder Legumes. Animal Feed Science and Technology. 119:345-361.

Wahlberg, M.L. 2009. Alternative Feeds for Beef Cattle. Virginia Cooperative Extension Publication 400-230. Virginia Polytechnic Institute and State University, Blacksburg.

Waller, P.J., Echevarria, F.E., Eddi, C., Maciel, S., Nari, A., and J.W. Hansen. 1996. The Prevalence of Anthelmintic Resistance in Nematode Parasites of Sheep in Southern Latin America: General Overview. Veterinary Parasitology. 62:181187.

Wang, Y., Waghorn, G.C., Douglas, G.B., Barry, T.N., and G.F. Wilson. 1994. The Effects of the Condensed Tannin in Lotus corniculatus upon nutrient metabolism and upon body and wool growth in grazing sheep. Proceedings of the New Zealand Society of Animal Production. 54:219-222.

Wang, Y., Waghorn, G.C., McNabb, W.C., Barry, T.N., Hedley, M., and I. Shelton. 1996. Effect of Condensed Tannins in Lotus corniculatus Upon the Digestion of Methionine and Cystine in the Small Intestine of Sheep. Journal of Agricultural Science Cambridge. 127:413-421.

Weir, W.C., Meyer, J.H., Garrett, W.N., Lofgreen, G.P., and N.R. Ittner. 1959. Pelleted Rations Compared to Similar Rations Fed Chopped or Ground for Steers and Lambs. Journal of Animal Science. 18:805-814.

Wilkins, H.L., Bates, R.P., and P.R. Henson. 1953. Tannin and Palatability in Sericea Lespedeza, L. cuneata. Agronomy Journal. 45:335-356.

Winowiski, T. 1988. Wheat and Pellet Quality. Feed Management. 39:58-64.

Wondra, K.J., Hancock, J.D., Behnke, K.C., Hines, R.H., and C.R. Stark. 1995. Effects of Particle Size and Pelleting on Growth Performance, Nutrient Digestibility, and Stomach Morphology in Finishing Pigs. Journal of Animal Science. 73:757-763.

Woodward, S.L., Auldist, M.J., Laboyrie, P.J., and E.B.L. Jansen. 1999. Effect of Lotus corniculatus and Condensed Tannins on Milk Yield and Milk Composition of Dairy Cows. Proceedings of the New Zealand Society of Animal Production. 59:152-155. 
Yu, F., Barry, T.N., McNabb, W.C., Moughan, P.J., and G.F. Wilson. 1995. Effect of Bound Condensed Tannin from Cottonseed Upon In situ Protein Solubility and Dry Matter Degradation in the Rumen. Journal of the Science of Food and Agriculture. 69:311-319.

Zelinsky, R., Daniel, J.A., and J.E. Held. 2006. The Effect of Corn or Soybean Hull Diets Supplemented with Dried Distillers Grain with Solubles (DDGS) on Finishing Lamb Performance and Carcass Merit. South Dakota State University Sheep Research Report - 2006 - 3. South Dakota State University, Brookings.

Zelter, S.Z., LeRoy, F., and J.P. Tissier. 1970. Protection of Feed Proteins Against Bacterial Deamination in the Rumen. Annales de Biologie Animale Biochimie Biophysique. 10:123-141.

Zimonja, O., Sevnebo, A., and B. Svihus. 2007. Nutritional Value of Diets for Broiler Chickens as Affected by Fat Source, Amylose Level and Diet Processing. Canadian Journal of Animal Science. 87:553-562. 


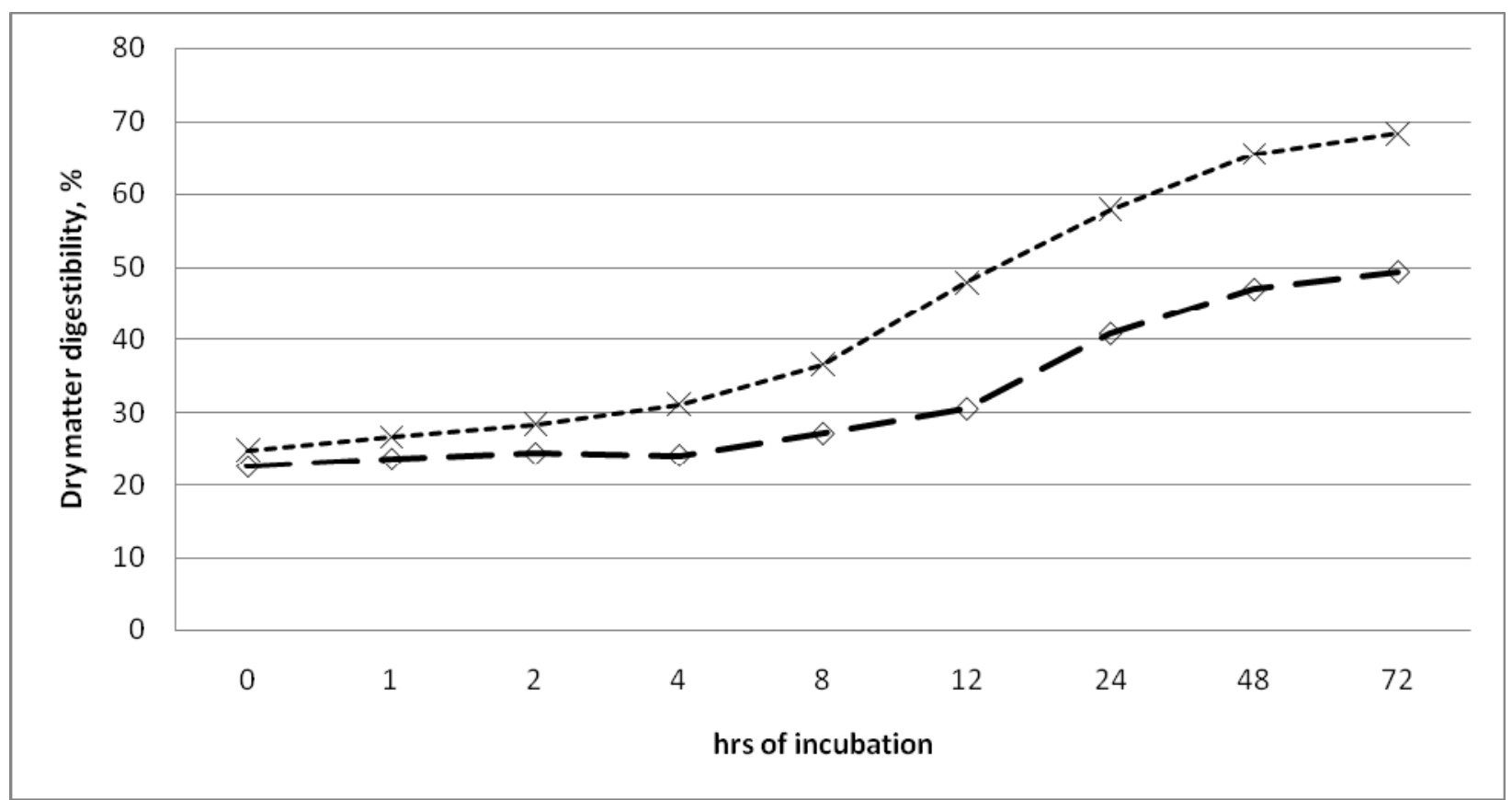

Figure 1. In-situ dry matter digestibility of tulip poplar (- - $)$ and white oak (- - ) leaf meals. Data are presented as least square means of triplicate digestions within the rumens of two non-lactating dairy cows fed a corn silage- and grass haylage-based diet; largest $\mathrm{SEM}=0.71$. Means comparisons differed $(\mathrm{P}<0.05)$ at all time points between leaf meals. No differences $(\mathrm{P}>0.10)$ were detected for any time point comparisons between 0 and 4 hrs of incubation for white oak leaf meal with all other white oak leaf meal incubations increasing in dry matter digestibility at measured time points post 4 hours. Dry matter digestibility's of $0 \mathrm{vs} .1 \mathrm{hr}$ and $1 \mathrm{vs} .2 \mathrm{hr}$ tulip poplar leaf meal incubations tended ( $\mathrm{P}=0.06$ and 0.08 , respectively) to differ, while all tulip poplar leaf meal incubations at measured time points post 2 hours demonstrated increasing $(\mathrm{P}<$ 0.05) dry matter digestibility. 
Table 1. Ingredient composition of pelleted experimental growing lamb diets ${ }^{1}$.

\begin{tabular}{|c|c|c|c|c|c|}
\hline & BA & LOLM & HOLM & LPLM & HPLM \\
\hline Ingredient & \multicolumn{5}{|c|}{$\%$ of DM } \\
\hline Soybean Hull Pellets, Ground ${ }^{2}$ & 20.00 & 10.00 & -- & 10.00 & -- \\
\hline Soybean Meal & 18.15 & 19.77 & 21.42 & 19.58 & 21.01 \\
\hline Whole Oats, Ground ${ }^{2}$ & 15.00 & 15.00 & 15.00 & 15.00 & 15.00 \\
\hline Alfalfa Cubes, Ground ${ }^{2}$ & 15.00 & 15.00 & 15.00 & 15.00 & 15.00 \\
\hline Pelleted Beet Pulp, Ground ${ }^{2}$ & 14.00 & 14.00 & 14.00 & 14.00 & 14.00 \\
\hline Shelled Corn, Ground ${ }^{2}$ & 12.35 & 10.73 & 9.08 & 10.95 & 9.49 \\
\hline White Oak Leaf Meal & -- & 10.00 & 20.00 & -- & -- \\
\hline Tulip Poplar Leaf Meal & -- & -- & -- & 10.00 & 20.00 \\
\hline Soybean Oil & 4.00 & 4.00 & 4.00 & 4.00 & 4.00 \\
\hline Salt & 0.50 & 0.50 & 0.50 & 0.50 & 0.50 \\
\hline Mineral Premix ${ }^{3}$ & 0.50 & 0.50 & 0.50 & 0.50 & 0.50 \\
\hline Vitamin Premix ${ }^{4}$ & 0.50 & 0.50 & 0.50 & 0.50 & 0.50 \\
\hline
\end{tabular}

${ }^{1}$ Dietary treatments: Basal control (BA) diet contained $20 \% \mathrm{SBH}$ and did not replace any $\%$ of SBH with leaf meal; Low oak leaf meal (LOLM) diet replaced $50 \%$ of DM from SBH (10\% of total dietary DM) with white oak leaf meal; High oak leaf meal (HOLM) diet replaced $100 \%$ of DM from SBH (20\% of total dietary DM) with white oak leaf meal; Low poplar leaf meal (LPLM) diet replaced $50 \%$ of DM from SBH (10\% of total dietary DM) with tulip poplar leaf meal; High poplar leaf meal (HPLM) diet replaced 100 $\%$ of DM from SBH (20\% of total dietary DM) with tulip poplar leaf meal.

${ }^{2}$ Ingredients were ground through a $3.175 \mathrm{~mm}$ screen utilizing a hammer mill prior to mixing.

${ }^{3}$ Mineral Premix consisted of a minimum of $19 \% \mathrm{Ca}, 3 \% \mathrm{P}, 2.5 \% \mathrm{Mg}, 3 \% \mathrm{~S}, 2.4 \% \mathrm{~K}$, $15 \% \mathrm{NaCl}, 0.24 \% \mathrm{Fe}, 0.27 \% \mathrm{Zn}, 0.24 \% \mathrm{Mn}, 0.004 \% \mathrm{I}, 0.003 \% \mathrm{Co}$, and $0.0024 \% \mathrm{Se}$ on a DM basis.

${ }^{4}$ Vitamin Premix consisted of a minimum of 3,080,000 IU/kg of Vitamin A, 1, 100,000 $\mathrm{IU} / \mathrm{kg}$ of Vitamin $\mathrm{D}_{3}$, and $6,600 \mathrm{IU} / \mathrm{kg}$ of Vitamin $\mathrm{E}$ on a DM basis. 
Table 2. Proximate analysis and fiber determination ${ }^{1}$ of pelleted experimental growing lamb diets ${ }^{2}$.

\begin{tabular}{|l|c|c|c|c|c|}
\hline & BA & LOLM & HOLM & LPLM & HPLM \\
\hline Item & \multicolumn{5}{|c|}{ \% of DM } \\
\hline DM & 88.98 & 90.06 & 89.86 & 89.77 & 89.42 \\
\hline CP & 19.74 & 17.35 & 20.05 & 19.06 & 20.20 \\
\hline SCP & 5.11 & 4.37 & 5.52 & 7.01 & 6.25 \\
\hline NDF & 31.63 & 32.84 & 31.95 & 31.07 & 30.29 \\
\hline CPNDF & 5.75 & 7.09 & 6.02 & 7.46 & 7.27 \\
\hline ADF & 18.36 & 18.64 & 14.04 & 14.83 & 16.32 \\
\hline CPADF & 1.22 & 1.16 & 1.99 & 2.01 & 1.57 \\
\hline ADL & 5.73 & 6.95 & 9.30 & 6.19 & 7.23 \\
\hline OM & 94.03 & 93.41 & 93.16 & 92.98 & 93.04 \\
\hline
\end{tabular}

${ }^{\mathrm{I}} \mathrm{DM}=$ Dry matter; $\mathrm{CP}=$ Crude protein; $\mathrm{SCP}=$ Soluble crude protein; $\mathrm{NDF}=$ Neutral detergent fiber; $\mathrm{CPNDF}=$ Crude protein bound to neutral detergent fiber; $\mathrm{ADF}=\mathrm{Acid}$ detergent fiber; $\mathrm{CPADF}=$ Crude protein bound to acid detergent fiber; $\mathrm{ADL}=$ Acid detergent lignin; $\mathrm{OM}=$ Organic matter.

${ }^{2}$ Dietary treatments: Basal control (BA) diet contained $20 \%$ SBH and did not replace any $\%$ of SBH with leaf meal; Low oak leaf meal (LOLM) diet replaced $50 \%$ of DM from SBH (10\% of total dietary DM) with white oak leaf meal; High oak leaf meal (HOLM) diet replaced $100 \%$ of DM from SBH ( $20 \%$ of total dietary DM) with white oak leaf meal; Low poplar leaf meal (LPLM) diet replaced $50 \%$ of DM from SBH (10 \% of total dietary DM) with tulip poplar leaf meal; High poplar leaf meal (HPLM) diet replaced $100 \%$ of DM from SBH (20\% of total dietary DM) with tulip poplar leaf meal. 
Table 3. Proximate analysis and fiber determination ${ }^{1}$ of white oak and tulip poplar leaf meals.

\begin{tabular}{|l|c|c|}
\hline & $\begin{array}{c}\text { White Oak } \\
\text { Leaf Meal }\end{array}$ & $\begin{array}{c}\text { Tulip Poplar } \\
\text { Leaf Meal }\end{array}$ \\
\hline Item & \multicolumn{2}{|c|}{$\%$ of DM } \\
\hline DM & 91.50 & 94.25 \\
\hline CP & 5.99 & 6.81 \\
\hline SCP & 1.26 & 1.18 \\
\hline NDF & 39.93 & 36.25 \\
\hline CPNDF & 1.37 & 1.82 \\
\hline ADF & 30.23 & 25.18 \\
\hline CPADF & 0.99 & 0.95 \\
\hline ADL & 8.89 & 6.15 \\
\hline OM & 95.31 & 91.76 \\
\hline
\end{tabular}

${ }^{\mathrm{I}} \mathrm{DM}=$ Dry matter; $\mathrm{CP}=$ Crude protein; $\mathrm{SCP}=$ Soluble crude protein; $\mathrm{NDF}=$ Neutral detergent fiber; $\mathrm{CPNDF}=$ Crude protein bound to neutral detergent fiber; $\mathrm{ADF}=\mathrm{Acid}$ detergent fiber; $\mathrm{CPADF}=$ Crude protein bound to acid detergent fiber; $\mathrm{ADL}=\mathrm{Acid}$ detergent lignin; $\mathrm{OM}=$ Organic matter. 
Table 4. Phenol analysis ${ }^{1}$ of white oak and tulip poplar leaf meals.

\begin{tabular}{|l|c|c|c|c|}
\hline & \multicolumn{2}{|c|}{ TRT } & \multicolumn{2}{c|}{ Fixed Effects } \\
\hline Item & $\begin{array}{c}\text { White Oak } \\
\text { Leaf Meal }\end{array}$ & $\begin{array}{c}\text { Tulip Poplar } \\
\text { Leaf Meal }\end{array}$ & SEM & P value \\
\hline TPC, CE & $5.40^{\mathrm{a}}$ & $0.31^{\mathrm{b}}$ & 0.01 & $<0.001$ \\
\hline PPC, CE & $1.22^{\mathrm{a}}$ & $0.33^{\mathrm{b}}$ & 0.03 & 0.002 \\
\hline
\end{tabular}

${ }^{1} \mathrm{TPC}=$ Total Phenolic Compounds; $\mathrm{PPC}=$ Protein Precipitating Capability; $\mathrm{CE}=$ Catechin equivalents in $\mathrm{mg}$ of Catechin per $100 \mathrm{mg}$ of sample.

${ }^{\mathrm{a}, \mathrm{b}}$ Within row, data with different superscripts differ $(\mathrm{P}<0.05)$. 
Table 5. Phenol analysis ${ }^{1}$ of pelleted and non-pelleted experimental growing lamb diets ${ }^{2}$.

\begin{tabular}{|c|c|c|c|c|c|c|c|c|c|c|c|c|c|c|}
\hline & \multicolumn{5}{|c|}{ Non-Pelleted } & \multicolumn{5}{|c|}{ Pelleted } & & \multicolumn{3}{|c|}{ P value } \\
\hline ITEM & BA & LOLM & HOLM & LPLM & HPLM & BA & LOLM & HOLM & LPLM & HPLM & $\begin{array}{c}\text { Pooled } \\
\text { SEM }\end{array}$ & Diet & Pellet & $\begin{array}{l}\text { Diet } \mathrm{X} \\
\text { Pellet }\end{array}$ \\
\hline $\begin{array}{l}\text { TPC, } \\
\text { CE }\end{array}$ & $0.98^{\mathrm{ab}}$ & $1.37^{\mathrm{c}}$ & $1.95^{\mathrm{d}}$ & $1.01^{\mathrm{ab}}$ & $1.01^{\mathrm{ab}}$ & 0.37 & $1.05^{\mathrm{b}}$ & $1.31^{\mathrm{c}}$ & $0.91^{\mathrm{a}}$ & $0.94^{\mathrm{a}}$ & 0.04 & $<0.01$ & $<0.01$ & $<0.01$ \\
\hline $\begin{array}{l}\text { PPC, } \\
\text { CE }\end{array}$ & $0.49^{\mathrm{cd}}$ & $0.55^{\mathrm{d}}$ & $0.57^{\mathrm{d}}$ & $0.49^{\mathrm{cd}}$ & 0.81 & $0.49^{\mathrm{cd}}$ & $0.33^{\mathrm{ab}}$ & $0.37^{\mathrm{b}}$ & $0.23^{\mathrm{a}}$ & $0.43^{b c}$ & 0.03 & $<0.01$ & $<0.01$ & $<0.01$ \\
\hline
\end{tabular}

${ }^{1} \mathrm{TPC}=$ Total phenolic compounds; $\mathrm{PPC}=$ Protein precipitating capacity; $\mathrm{CE}=$ Catechin equivalents measured in $\mathrm{mg}$ Catechin/100mg sample.

${ }^{2}$ Dietary treatments: Basal control (BA) diet contained $20 \%$ SBH and did not replace any \% of SBH with leaf meal; Low oak leaf meal (LOLM) diet replaced $50 \%$ of DM from SBH (10\% of total dietary DM) with white oak leaf meal; High oak leaf meal (HOLM) diet replaced $100 \%$ of DM from SBH (20\% of total dietary DM) with white oak leaf meal; Low poplar leaf meal (LPLM) diet replaced $50 \%$ of DM from SBH (10\% of total dietary DM) with tulip poplar leaf meal; High poplar leaf meal (HPLM) diet replaced $100 \%$ of DM from SBH (20\% of total dietary DM) with tulip poplar leaf meal.

${ }^{\mathrm{a}, \mathrm{b}, \mathrm{c}, \mathrm{d}}$ Within row, data with different superscripts differ $(\mathrm{P}<0.05)$. 
Table 6. Pellet quality ${ }^{1}$ of experimental growing lamb diets ${ }^{2}$.

\begin{tabular}{|l|c|c|c|c|c|c|c|c|}
\hline & \multicolumn{5}{|c|}{ TRT } & \multicolumn{3}{c|}{ Fixed Effects } \\
\hline Item & BA & LOLM & HOLM & LPLM & HPLM & SEM & SD & P value \\
\hline PDI & $80.45^{\mathrm{c}}$ & $76.80^{\mathrm{d}}$ & $82.90^{\mathrm{b}}$ & $83.10^{\mathrm{b}}$ & $86.55^{\mathrm{a}}$ & 0.48 & 3.26 & $<0.001$ \\
\hline MPDI & $64.55^{\mathrm{c}}$ & $56.80^{\mathrm{d}}$ & $69.40^{\mathrm{b}}$ & $65.35^{\mathrm{c}}$ & $74.30^{\mathrm{a}}$ & 0.46 & 5.81 & $<0.001$ \\
\hline
\end{tabular}

${ }^{1} \mathrm{PDI}=$ Pellet durability index; MPDI $=$ Modified pellet durability index.

${ }^{2}$ Dietary treatments: Basal control (BA) diet contained $20 \%$ SBH and did not replace any $\%$ of SBH with leaf meal; Low oak leaf meal (LOLM) diet replaced $50 \%$ of DM from SBH (10\% of total dietary DM) with white oak leaf meal; High oak leaf meal (HOLM) diet replaced $100 \%$ of DM from SBH (20\% of total dietary DM) with white oak leaf meal; Low poplar leaf meal (LPLM) diet replaced $50 \%$ of DM from SBH (10\% of total dietary DM) with tulip poplar leaf meal; High poplar leaf meal (HPLM) diet replaced 100 $\%$ of DM from SBH (20\% of total dietary DM) with tulip poplar leaf meal.

${ }^{a, b, c, c, d}$ Within row, data with different superscripts differ $(\mathrm{P}<0.05)$. 
Table 7. Dry matter intake ${ }^{1}$ and In vivo digestibility ${ }^{2}$ of pelleted experimental growing lamb diets ${ }^{3}$.

\begin{tabular}{|l|c|c|c|c|c|c|c|}
\hline & \multicolumn{5}{|c|}{ TRT } & \multicolumn{2}{c|}{ Fixed Effects } \\
\hline Item & BA & LOLM & HOLM & LPLM & HPLM & SEM & P value \\
\hline DMI, \% BW & 0.84 & 0.89 & 0.84 & 0.82 & 0.84 & 0.07 & 0.674 \\
\hline DMD & $74.76^{\mathrm{a}}$ & $68.56^{\mathrm{b}}$ & $67.83^{\mathrm{b}}$ & $68.10^{\mathrm{b}}$ & $71.12^{\mathrm{ab}}$ & 2.33 & 0.007 \\
\hline NDFD & $49.27^{\mathrm{a}}$ & $36.54^{\mathrm{bc}}$ & $39.86^{\mathrm{bc}}$ & $35.08^{\mathrm{c}}$ & $44.02^{\mathrm{ab}}$ & 3.92 & 0.011 \\
\hline ADFD & $81.87^{\mathrm{a}}$ & $67.68^{\mathrm{b}}$ & $67.06^{\mathrm{b}}$ & $70.05^{\mathrm{b}}$ & $76.35^{\mathrm{ab}}$ & 4.30 & 0.004 \\
\hline CPD & 66.81 & 64.89 & 64.10 & 60.43 & 62.64 & 4.15 & 0.355 \\
\hline OMD & $57.09^{\mathrm{a}}$ & $50.60^{\mathrm{b}}$ & $52.66^{\mathrm{ab}}$ & $50.51^{\mathrm{b}}$ & $51.63^{\mathrm{ab}}$ & 3.51 & 0.048 \\
\hline
\end{tabular}

${ }^{\mathrm{I}} \mathrm{DMI}, \% \mathrm{BW}=$ Dry matter intake expressed as a percentage of body weight.

${ }^{2} \mathrm{DMD}=$ Dry matter digestibility; NDFD = Neutral detergent fiber digestibility; ADFD = Acid detergent fiber digestibility; $\mathrm{CPD}=$ Crude protein digestibility; $\mathrm{OMD}=$ Organic matter digestibility.

${ }^{3}$ Dietary treatments: Basal control (BA) diet contained $20 \% \mathrm{SBH}$ and did not replace any $\%$ of SBH with leaf meal; Low oak leaf meal (LOLM) diet replaced $50 \%$ of DM from SBH (10\% of total dietary DM) with white oak leaf meal; High oak leaf meal (HOLM) diet replaced $100 \%$ of DM from SBH (20\% of total dietary DM) with white oak leaf meal; Low poplar leaf meal (LPLM) diet replaced $50 \%$ of DM from SBH (10\% of total dietary DM) with tulip poplar leaf meal; High poplar leaf meal (HPLM) diet replaced $100 \%$ of DM from SBH (20\% of total dietary DM) with tulip poplar leaf meal. ${ }^{\mathrm{a}, \mathrm{b}, \mathrm{c}}$ Within row, data with different superscripts differ $(\mathrm{P}<0.05)$. 
Table 8. In vivo nitrogen metabolism ${ }^{1}$ of pelleted experimental growing lamb $\operatorname{diets}^{2}$.

\begin{tabular}{|l|c|c|c|c|c|c|c|c|c|}
\hline & \multicolumn{5}{|c|}{ TRT } & \multicolumn{3}{c|}{ Main Effects } & Interaction \\
\hline Item & BA & LOLM & HOLM & LPLM & HPLM & SEM & TRT & Time & TRT x Time \\
\hline $\begin{array}{l}\text { PUN, } \\
\mathrm{mg} / \mathrm{dL}\end{array}$ & $613.83^{\mathrm{ab}}$ & $446.48^{\mathrm{c}}$ & $562.50^{\mathrm{b}}$ & $650.87^{\mathrm{a}}$ & $640.88^{\mathrm{a}}$ & 42.66 & $<0.001$ & 0.063 & 0.913 \\
\hline $\begin{array}{l}\text { UUN, } \\
\mathrm{mg} / \mathrm{dL}\end{array}$ & 56.91 & 48.69 & 52.02 & 64.28 & 87.02 & 59.77 & 0.921 & -- & -- \\
\hline $\begin{array}{l}\text { UCP, } \\
\%\end{array}$ & 5.39 & 4.31 & 4.24 & 5.59 & 6.70 & 1.52 & 0.568 & -- & -- \\
\hline
\end{tabular}

${ }^{1} \mathrm{PUN}=$ Plasma urea nitrogen; UUN = Urinary urea nitrogen; $\mathrm{UCP}=$ Urinary crude protein.

${ }^{2}$ Dietary treatments: Basal control (BA) diet contained $20 \%$ SBH and did not replace any \% of SBH with leaf meal; Low oak leaf meal (LOLM) diet replaced $50 \%$ of DM from SBH (10\% of total dietary DM) with white oak leaf meal; High oak leaf meal (HOLM) diet replaced $100 \%$ of DM from SBH (20\% of total dietary DM) with white oak leaf meal; Low poplar leaf meal (LPLM) diet replaced $50 \%$ of DM from SBH (10\% of total dietary DM) with tulip poplar leaf meal; High poplar leaf meal (HPLM) diet replaced $100 \%$ of DM from SBH (20\% of total dietary DM) with tulip poplar leaf meal.

${ }^{\mathrm{a}, \mathrm{b}, \mathrm{c}}$ Within row, data with different superscripts differ $(\mathrm{P}<0.05)$. 
Utilization of Leaf Meal as a Potential Feed Source

Jason K. Smith

Thesis submitted to the Davis College of Agriculture, Natural Resources and Design at West Virginia University in partial fulfillment of the requirements for the degree of

Master of Science

in

Animal and Nutritional Sciences

Division of Animal and Nutritional Sciences

APPROVAL OF THE EXAMINING COMMITTEE

Eugene E.D. Felton, Ph.D., Chair

Joseph S. Moritz III, Ph.D.

Date

John E. Warren, Ph.D.

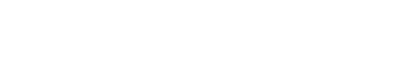

